\title{
37. UPPER CENOZOIC CALCAREOUS NANNOFOSSIL BIOSTRATIGRAPHY, CÔTE D'IVOIRE-GHANA MARGIN, EASTERN EQUATORIAL ATLANTIC ${ }^{1}$
}

\author{
Samir Shafik, ${ }^{2}$ David K. Watkins, ${ }^{3}$ and Im Chul Shin ${ }^{4}$
}

\begin{abstract}
The distribution of calcareous nannofossils in the upper Cenozoic sections sampled at four sites in the eastern equatorial Atlantic Ocean during Ocean Drilling Program (ODP) Leg 159 is documented here. A virtually complete upper Cenozoic sequence of nannofossil (sub)zones is identified at Site 959 on the shoulder of the Côte d'Ivoire-Ghana marginal ridge, with proxies for the rare marker species being employed. Hiatuses within the middle and upper Miocene are detected at two other sites on the same ridge, being more clearly defined at Site 960 on the crest of the ridge. Two of these hiatuses are of regional significance. A middle Miocene hiatus, based on a truncated Zone CN4, absent Zone CN5, and reduced Zone CN6, could probably be related to a major change in the depositional regime at Site 959, when a mid-Cenozoic series of short episodes of deposition of non-calcareous sediments ended. A late Miocene hiatus, based on the absence of Subzone CN8a in all sites on the ridge, is seemingly coeval with another one previously documented in oceanic sections elsewhere. Two other late Miocene hiatuses, based on the absence of Subzones CN7a and CN9a, coupled with a very thin Zone CN6, indicate a sediment starvation of the ridge during much of the middle and late Miocene. The timing of the hiatuses suggests a correspondence with major falls in sea level.
\end{abstract}

\section{INTRODUCTION}

The aim of this study is to document the distribution of calcareous nannofossils in the upper Cenozoic sections of four sites cored during Ocean Drilling Program Leg 159, all located in the eastern equatorial Atlantic Ocean, to determine their biostratigraphy and help interpret their geological history. Three relatively shallow sites (Sites 959, 960, and 961) are located on the Côte d'Ivoire-Ghana marginal ridge, and a fourth deeper site (Site 962) is on an associated minor ridge (Fig. 1).

One of the main objectives of Leg 159 was to improve the continuity and resolution of tropical Atlantic microfossil biostratigraphy. Site 959 , being on the sheltered shoulder of the ridge where sedimentation rates were relatively high (see Mascle, Lohmann, Clift, et al., 1996), provided an almost complete upper Cenozoic section. Two holes at this site were studied: Hole 959A, which penetrated the entire upper Cenozoic including the Oligocene/Miocene transition; and Hole 959B, which provided additional information from the middle Miocene/Pliocene part.

Upper Cenozoic sections at other Leg 159 sites are significantly thinner than the one at Site 959 and were found to contain more unconformities. In oceanic sections, recognition of a hiatus (i.e., the geological time that an unconformity represents) is largely a function of the available stratigraphic resolution, which is very much dependent on the tools used (e.g., biostratigraphic, magnetostratigraphic, etc., either singularly or combined), their reliability, and the density of sampling. Calcareous nannofossils have long been acknowledged as a powerful biostratigraphic tool, with a fine resolution in most of the Cenozoic (averaging $1 \mathrm{~m} . \mathrm{y}$. per subzone for the Neogene, and

${ }^{1}$ Mascle, J., Lohmann, G.P., and Moullade, M. (Eds.), 1998. Proc. ODP, Sci. Results, 159: College Station, TX (Ocean Drilling Program).

${ }^{2}$ Australian Geological Survey Organization, GPO Box 378, Canberra ACT 2601, Australia.sshafik@agso.gov.au

${ }^{3}$ Department of Geology, University of Nebraska-Lincoln, Lincoln, NE 69588-0340 U.S.A

${ }^{4}$ Korea Ocean Research Institute, Ansan, P.O. Box 29, Seoul, 325-600 Korea. finer for the Pleistocene; see Berggren et al., 1995b). However, fine stratigraphic resolution may not be achievable where marker species are unable to be used effectively (e.g., the species is rare or sporadic in occurrence). Choosing an appropriate, consistently occurring, easily identifiable species as a proxy for an unsuitable marker, while documenting occurrences of the latter, is one way of maintaining the fine resolution. This practice is followed in this study.

\section{METHODS}

Assemblages were analyzed from smear slides prepared using either raw sediment samples (core-catcher samples) or sediment suspensions in distilled water (other samples). For each sample, two slides were prepared, one with double the number of suspension drops used for the other. Slides were examined with an optical microscope at $1250 \times$ magnification. At least one sample from every second core section was examined. The relative abundance of species was estimated for all assemblages except those in Hole 959B.

Estimates for the total nannofossil abundance in a slide were determined as follows: D (dominant) $=>60 \%$ of all particles; A (abundant $)=30 \%-60 \%$ of all particles; $\mathrm{C}$ (common) $=10 \%-30 \%$ of all particles; $\mathrm{F}(\mathrm{few})=5 \%-10 \%$ of all particles; $\mathrm{R}($ rare $)=1 \%-5 \%$ of all particles; $\mathrm{T}($ trace $)=<1 \%$ of all particles. Estimates of nannofossil preservation are coded as follows: $\mathrm{E}$ (excellent) $=$ pristine preservation with no overgrowth or dissolution; $\mathrm{G}$ (good) = slight dissolution and overgrowth, but all taxa are easily identifiable; $\mathbf{M}$ (moderate) $=$ obvious signs of dissolution and overgrowth, but most specimens are readily identifiable; $\mathrm{P}$ (poor) = strong overgrowth and dissolution, and most specimens are fragmented and difficult to identify. Estimates of the relative abundances of nannofossil species were determined as follows: $\mathrm{D}$ (dominant) $=>60 \%$ of all nannofossils; $\mathrm{A}$ (abundant $)=30 \%-60 \%$ of all nannofossils; $\mathrm{C}$ (common $)=10 \%-30 \%$ of all nannofossils; $\mathrm{F}$ (few) $=5 \%-10 \%$ of all nannofossils; $\mathrm{R}$ (rare) $=1 \%$ $5 \%$ of all nannofossils; vR (very rare) $=<1 \%$ of all nannofossils. Where these estimates were not determined the letter $\mathrm{X}$ is indicated instead. 


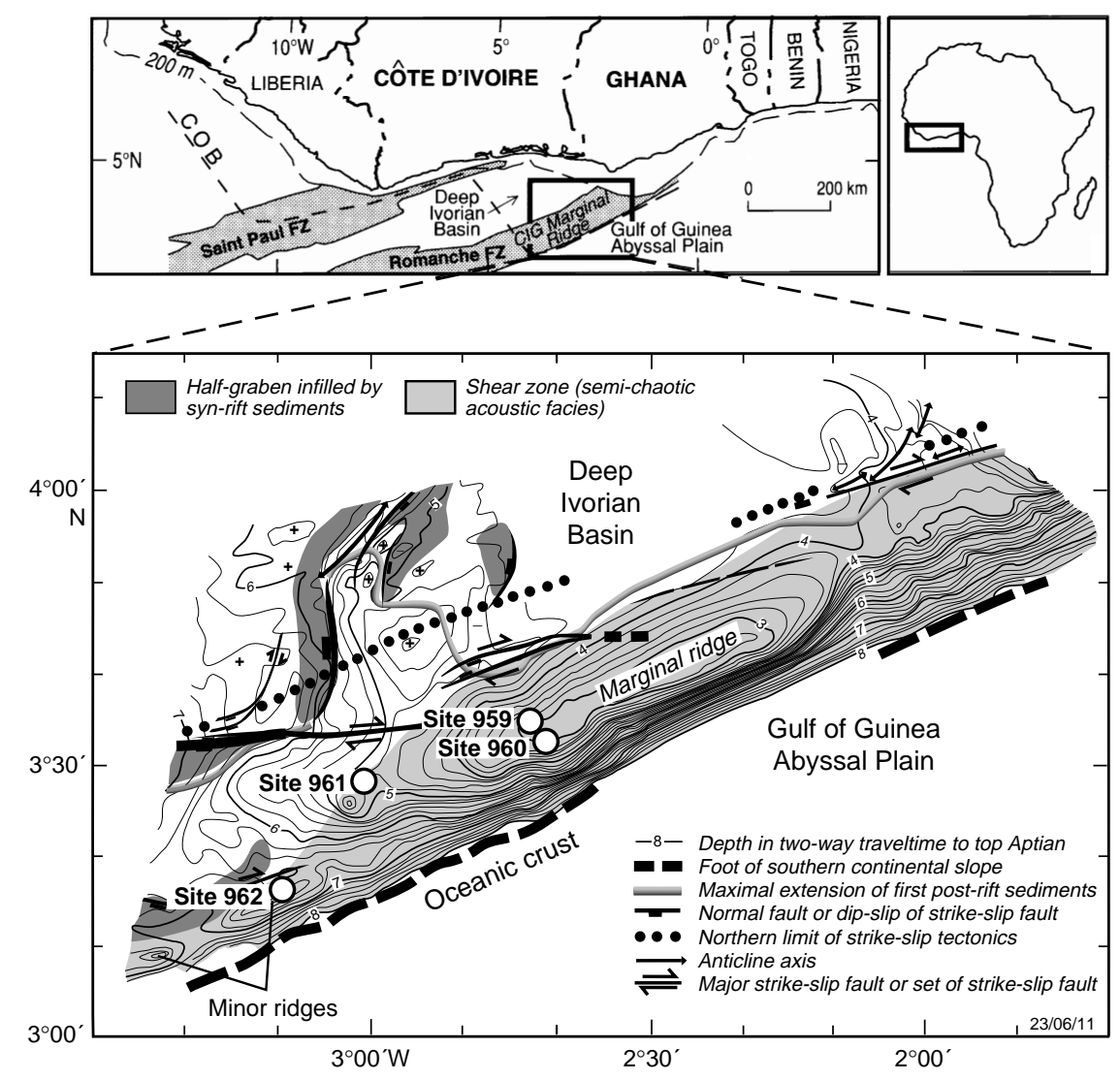

\section{NANNOFOSSIL DISTRIBUTION AND BIOSTRATIGRAPHY}

The distribution of calcareous nannofossils in the upper Cenozoic sections off the Côte d'Ivoire and Ghana is given in Tables 1-6 (backpocket foldout, this volume). A biostratigraphic summary is presented in Figure 2 and is discussed below. We have used primarily the CN (sub)zones of Okada and Bukry (1980) because of their greater resolution, particularly in the upper Miocene. This zonation is largely based on biozones originally described by other authors (e.g. Bramlette and Wilcoxon, 1967; Gartner, 1969; Martini, 1971; Bukry, 1973, 1975), and is mostly applicable for low-latitude oceanic areas.

Zonal boundaries tended to be more confidently identified than subzonal boundaries at Site 959, the most complete upper Cenozoic record we have on the Côte d'Ivoire-Ghana marginal ridge (see below). The uncertainty usually was a result of the marker species being rare or sporadic in occurrence. This led us to either rank (sub)zonal indicators differently than originally intended by their authors or to adopt proxies for the original index species (see "Biostratigraphic Summary and Remarks," below). As shown in Figure 2, we have used the lowest occurrence (LO) of Orthorhabdus serratus to mark the base of Subzone CN1c instead of the LO of Discoaster druggii; the highest occurrence (HO) of Discoaster bollii to mark the top of Subzone CN8a instead of the LO of Discoaster neorectus, which was originally proposed for the base of $\mathrm{CN} 8 \mathrm{~b}$; the $\mathrm{HO}$ of Minylitha convalis to mark the top of Subzone CN9a instead of the LO of Amaurolithus primus, which was originally intended for the base of $\mathrm{CN} 9 \mathrm{~b}$; the LO of (circular, $>5 \mu \mathrm{m}$ ) Pseudoemiliania lacunosa to mark the base of Subzone CN11b instead of the advent of the acme of Discoaster asymmetricus; and the $\mathrm{HO}$ of Sphenolithus spp. to mark the top of Subzone CN11b in preference to the HO of Reticulofenestra pseudoumbilicus. The species Discoaster druggii, D. neorectus, and
A. primus are rare or sporadic in occurrence, whereas the acme of $D$. asymmetricus and the $\mathrm{HO}$ of $R$. pseudoumbilicus are difficult to locate precisely.

\section{Hole 959A (Water Depth 2090.7 m)}

An almost complete succession of upper Cenozoic calcareous nannofossil (sub)zones was identified in this hole. Several barren intervals interrupt the otherwise continuous succession of upper Oligocene and lower Miocene nannofossil assemblages; and a hiatus is detected within the upper Miocene.

The Uppermost Oligocene assemblages of Subzone CN1a are found in the interval comprising Samples from 159-959A-37X-CC through $32 \mathrm{X}-5,129-130 \mathrm{~cm}$; however, several samples within this interval are barren of calcareous nannofossils, in keeping with the deposition pattern of alternating barren and nannofossil-bearing beds in both the underlying upper Oligocene (Shafik et al., Chap. 32, this volume) and overlying lower Miocene. These assemblages include abundant Cyclicargolithus abisectus, C. floridanus, Discoaster deflandrei, and Triquetrorhabdulus carinatus, and lack Sphenolithus ciperoensis, Dictyococcites bisectus, Zygrhablithus bijugatus, which are present in underlying assemblages. Cyclicargolithus abisectus is frequent, rare or even absent in similar assemblages from Samples 159-959A-31X-CC through $29 \mathrm{X}-7,44-45 \mathrm{~cm}$. These are assigned to the earliest Miocene Subzone CN1b.

Assemblages of Subzones CN1a and CN1b, in Samples 159959A-32X-5, 129-130 cm, and 31X-CC, respectively, are separated by an impoverished/barren interval where the Oligocene/Miocene boundary lies. This interval comprises Samples 159-959A-32X-3, $120-121 \mathrm{~cm}$, through $32 \mathrm{X}-1,120-121 \mathrm{~cm}$ (mostly diatomite with clay and minor nannofossil chalk); the lowermost sample (159959A-32X-3, 120-121 cm), is almost barren of calcareous nannofos- 


\begin{tabular}{|c|c|c|c|c|c|c|c|c|c|c|c|}
\hline \multirow{2}{*}{ \& } & \multirow{2}{*}{$\begin{array}{l}\text { 등 } \\
\text { 흄 } \\
\end{array}$} & \multirow{2}{*}{$\begin{array}{l}\text { Martini } \\
(1971) \\
\text { modified }\end{array}$} & \multirow{2}{*}{\multicolumn{2}{|c|}{$\begin{array}{l}\text { Bukry and } \\
\text { Okada (1980) } \\
\text { (Sub) Zones }\end{array}$}} & \multicolumn{6}{|c|}{ Core-section, interval (cm) in hole: } & \multirow{2}{*}{$\begin{array}{l}\text { Events defining } \\
\text { (sub) zonal boundaries }\end{array}$} \\
\hline & & & & & 959A & 959B & 960A & 960C & $961 \mathrm{~A}$ & 962B & \\
\hline \multirow{5}{*}{$\begin{array}{l}\frac{\Phi}{0} \\
\frac{0}{0} \\
\frac{0}{0} \\
\frac{0}{0}\end{array}$} & \multirow{2}{*}{ 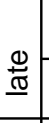 } & NN21 & \multicolumn{2}{|c|}{ CN15 } & $1 \mathrm{H}-1,50-51$ & \multirow{3}{*}{$1 \mathrm{H}-\mathrm{CC}$} & & \multirow{2}{*}{$\begin{array}{l}1 \mathrm{H}-1,17-19 \\
1 \mathrm{H}-3,30-31\end{array}$} & \multirow[t]{4}{*}{$1 \mathrm{R}-1,3-5$} & \multirow{3}{*}{ 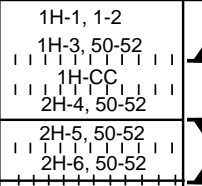 } & \\
\hline & & NN20 & \multirow{2}{*}{ CN14 } & b & $1 \mathrm{H}-2, \quad 100-101$ & & & & & & Psoudramilinis lacunns \\
\hline & \multirow{3}{*}{$\frac{\gtrsim}{\frac{\pi}{\varpi}}$} & \multirow{3}{*}{ NN19 } & & $\mathbf{a}$ & $\begin{array}{l}1 \mathrm{H}-4,100-101 \\
2 \mathrm{H}-1,100-101\end{array}$ & & $\begin{array}{c}1 \mathrm{R}-1,25-26 \\
1 \mathrm{R}-\mathrm{CC}\end{array}$ & $\begin{array}{l}1 \mathrm{H}-5,29-30 \\
2 \mathrm{H}-1,10-11\end{array}$ & & & 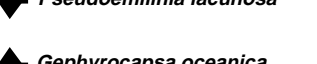 \\
\hline & & & \multirow{2}{*}{ CN13 } & b & $\begin{array}{l}2 \mathrm{H}-2,100-101 \\
2 \mathrm{H}-7,100-101\end{array}$ & $2 \mathrm{H}-\mathrm{CC}$ & ?? & $\begin{array}{l}2 \mathrm{H}-3,10-11 \\
2 \mathrm{H}-5,10-11 \\
\end{array}$ & & $2 \mathrm{H}-\mathrm{CC}$ & Gephyrocapsa caribbeanica \\
\hline & & & & a & $\begin{array}{l}\mathrm{H}-1,100-101 \\
3 \mathrm{H}-2,100-101\end{array}$ & $3 \mathrm{H}-6,55-57$ & 2R-CC & $2 \mathrm{H}-6,35-37$ & $1 \mathrm{R}-\mathrm{CC}$ & & \\
\hline \multirow{8}{*}{$\begin{array}{l}\text { @ } \\
\text { d } \\
\text { 음 } \\
\mathbf{\alpha}\end{array}$} & \multirow{4}{*}{$\stackrel{\oplus}{\underline{ \pm}}$} & NN18 & \multirow{4}{*}{ CN12 } & d & $\begin{array}{l}3 \mathrm{H}-3,100-101 \\
3 \mathrm{H}-5,100-101\end{array}$ & $\begin{array}{l}3 \mathrm{H}-7,55-57 \\
4 \mathrm{H}-2,59-61\end{array}$ & ?? & $\begin{array}{c}2 \mathrm{H}-\mathrm{CC} \\
3 \mathrm{H}-1,3-4\end{array}$ & \multirow{3}{*}{$\begin{array}{c}\text { (poor } \\
\text { core recovery) }\end{array}$} & & \\
\hline & & NN17 & & C & $\begin{array}{l}3 \mathrm{H}-6,100-101 \\
3 \mathrm{H}-\mathrm{CC}\end{array}$ & $\begin{array}{l}4 \mathrm{H}-3,59-61 \\
4 \mathrm{H}-6,59-61\end{array}$ & $3 R-1,7-8$ & $3 \mathrm{H}-3,13-14$ & & & ardatalus \\
\hline & & \multirow{2}{*}{ NN16 } & & b & $\begin{array}{l}4 \mathrm{H}-1,100-101 \\
4 \mathrm{H}-2,100-101\end{array}$ & 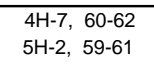 & $3 R-1,95-96$ & $\begin{array}{c}3 \mathrm{H}-3,130-131 \\
3 \mathrm{H}-\mathrm{CC}\end{array}$ & & \multirow{3}{*}{ 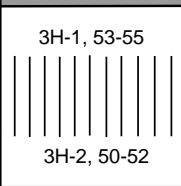 } & Discoaster surculus \\
\hline & & & & a & $\begin{array}{l}4 \mathrm{H}-3,100-101 \\
5 \mathrm{H}-4,100-101\end{array}$ & $\begin{array}{c}4 \mathrm{H}-\mathrm{CC} \\
5 \mathrm{H}-5,59-61\end{array}$ & $3 R-1,100-101$ & $\begin{array}{l}4 \mathrm{H}-1,129-130 \\
4 \mathrm{H}-3,130-131\end{array}$ & 2R-CC & & Sphenolithus spp. * \\
\hline & \multirow{4}{*}{$\frac{\lambda}{\frac{\pi}{\overparen{d}}}$} & \multirow{2}{*}{ NN15 } & \multirow{2}{*}{ CN11 } & b & $\begin{array}{l}5 \mathrm{H}-6,100-101 \\
6 \mathrm{H}-1,100-101\end{array}$ & $\begin{array}{l}5 \mathrm{H}-6,59-61 \\
7 \mathrm{H}-2,59-61\end{array}$ & $\begin{array}{c}3 R-C C \\
4 R-1,50-52\end{array}$ & $\begin{array}{l}4 \mathrm{H}-5,130-131 \\
5 \mathrm{H}-3,129-130\end{array}$ & $\begin{array}{c}\text { 3R-1, 34-35 } \\
\text { 3R-CC }\end{array}$ & & $\begin{array}{l}\text { R. pseudoumbilicus } \\
\text { Pseudoemiliania lacunosa * }\end{array}$ \\
\hline & & & & a & $\begin{array}{l}6 \mathrm{H}-2,100-101 \\
8 \mathrm{H}-1,100-101\end{array}$ & $\begin{array}{l}7 \mathrm{H}-3,59-61 \\
8 \mathrm{H}-4,59-61\end{array}$ & $\begin{array}{l}\text { 4R-1, } 105-106 \\
\text { 5R-CC }\end{array}$ & $5 \mathrm{H}-5,130-131$ & $? ?$ & \begin{tabular}{|c|}
$3 \mathrm{H}-3,50-52$ \\
$3 \mathrm{H}-\mathrm{C}^{\prime}, 50-1$ \\
$3 \mathrm{H}-\mathrm{CC}$
\end{tabular} & Acme $D$. asymmetricus \\
\hline & & $\begin{array}{l}\text { NN14/ } \\
\text { NN13 }\end{array}$ & & C & $\begin{array}{c}8 \mathrm{H}-2,100-101 \\
8 \mathrm{H}-\mathrm{CC} \\
\end{array}$ & $\begin{array}{l}8 \mathrm{H}-5,59-61 \\
8 \mathrm{H}-6,59-61\end{array}$ & $\begin{array}{c}\text { 6R-1, 10-11 } \\
6 \mathrm{R}-1,104-105 \\
\end{array}$ & $7 \mathrm{H}-1,130-131$ & $4 \mathrm{R}-1,89-91$ & & \\
\hline & & NN1? & CN10 & b & $\begin{array}{l}9 \mathrm{H}-1,100-101 \\
9 \mathrm{H}-3,100-101\end{array}$ & $\begin{array}{l}8 \mathrm{H}-7,59-61 \\
9 \mathrm{H}-7,59-61\end{array}$ & 6R-CC & $\begin{array}{c}7 \mathrm{H}-3,130-131 \\
7 \mathrm{H}-\mathrm{CC}\end{array}$ & $4 \mathrm{R}-1,117-118$ & & \\
\hline & & INIVI 2 & & $\mathbf{a}$ & $9 \mathrm{H}-5,100-101$ & $\begin{array}{l}10 \mathrm{H}-1,59-61 \\
10 \mathrm{H}-2,59-61\end{array}$ & $\begin{array}{l}\text { 7R-2, 29-30 } \\
\text { 7R-2, 106-108 }\end{array}$ & $\begin{array}{l}8 \mathrm{H}-1,130-131 \\
8 \mathrm{H}-3,130-131\end{array}$ & $? 4 \mathrm{R}-\mathrm{CC}$ & & Triquetrorhabdulus rugosus \\
\hline & & NN11 & CNa & b & $\begin{array}{c}9 \mathrm{H}-6,100-101 \\
13 \mathrm{H}-5,100-101\end{array}$ & $\begin{array}{l}10 \mathrm{H}-3,59-61 \\
14 \mathrm{H}-3,59-61\end{array}$ & $\begin{array}{l}\text { 7R-3, 30-31 } \\
\text { 9R-1, 3-4 }\end{array}$ & $\begin{array}{l}8 \mathrm{H}-4,34-46 \\
9 \mathrm{H}-6,34-36\end{array}$ & $\begin{array}{l}\text { 5R-1, 64-66 } \\
\text { 6R-CC }\end{array}$ & & Doveasier quinqueramis \\
\hline & & & UIve & $\mathbf{a}$ & $\begin{array}{l}13 \mathrm{H}-7,100-101 \\
14 \mathrm{H}-3,100-101\end{array}$ & $\begin{array}{l}14 \mathrm{H}-4,59-61 \\
15 \mathrm{H}-4,59-61\end{array}$ & & & 7R-CC & & litha convalis * \\
\hline & $\Phi$ & NN10 & CN8 & b & $\begin{array}{r}14 \mathrm{H}-4,100-101 \\
15 \mathrm{H}-5,100-101 \\
\end{array}$ & $\begin{array}{l}15 \mathrm{H}-5,59-61 \\
16 \mathrm{H}-3,59-61\end{array}$ & $\begin{array}{l}\text { 9R-1, 19-20 } \\
9 \mathrm{R}-1,29-30\end{array}$ & $\begin{array}{c}9 \mathrm{H}-7,64-65 \\
10 \mathrm{H}-3,34-36\end{array}$ & $\begin{array}{l}\text { 8R-1, 90-92 } \\
\text { 8R-CC }\end{array}$ & & scoaster neorectus \\
\hline & 艺 & & & $\mathbf{a}$ & & & & & ?? & & \\
\hline & & NN9 & CN7 & b & $\begin{array}{c}15 \mathrm{H}-6,100-101 \\
16 \mathrm{H}-\mathrm{CC}\end{array}$ & $\begin{array}{c}16 \mathrm{H}-4,59-61 \\
17 \mathrm{H}-2,59-61\end{array}$ & $\begin{array}{c}\text { 9R-1, 130-131 } \\
\text { 9R-2, 60-61 }\end{array}$ & $\begin{array}{c}10 \mathrm{H}-4,34-36 \\
10 \mathrm{H}-5,34-46\end{array}$ & $\begin{array}{c}\text { 9R-1, 100-102 } \\
\text { 9R-CC }\end{array}$ & & \\
\hline & & & & $\mathbf{a}$ & $17 \mathrm{H}-1,100-101$ & $\begin{array}{l}17 \mathrm{H}-3,59-61 \\
17 \mathrm{H}-4,59-61\end{array}$ & & & & & \\
\hline & & NN8 & CN6 & & $\begin{array}{c}17 \mathrm{H}-2,100-101 \\
17 \mathrm{H}-3,100-101\end{array}$ & $\begin{array}{l}17 \mathrm{H}-5,59-61 \\
17 \mathrm{H}-6,59-61\end{array}$ & $\begin{array}{l}9 \mathrm{R}-2,90 \\
9 \mathrm{R}-2,110\end{array}$ & $10 \mathrm{H}-6,34-36$ & & & \\
\hline & & NN7 & CN5 & b & $\begin{array}{l}17 \mathrm{H}-4,100-101 \\
18 \mathrm{H}-3,100-101\end{array}$ & $\begin{array}{l}17 \mathrm{H}-7,59-61 \\
19 \mathrm{H}-2,59-61\end{array}$ & & & (no data) & & Catinaster coalitus \\
\hline de & 음 & NN6 & UIvo & a & $\begin{array}{l}18 \mathrm{H}-5,100-101 \\
19 \mathrm{H}-1,100-101\end{array}$ & $\begin{array}{l}19 \mathrm{H}-3,59-61 \\
19 \mathrm{H}-5,59-61\end{array}$ & & & & & \\
\hline 을 & $E$ & NN5 & CN4 & & $\begin{array}{l}19 \mathrm{H}-5,100-101 \\
20 \mathrm{X}-7,35-36\end{array}$ & $\begin{array}{l}20 \mathrm{H}-2,59-61 \\
20 \mathrm{H}-\mathrm{CC}\end{array}$ & $\begin{array}{l}\text { 9R-2, 140-141 } \\
\text { 9R-CC }\end{array}$ & $\begin{array}{l}10 \mathrm{H}-7,34-36 \\
11 \mathrm{H}-4,34-36\end{array}$ & $11 \mathrm{R}-\mathrm{CC}$ & & \\
\hline & & NN4 & CN3 & & \begin{tabular}{|l|}
$21 X-1,100-101$ \\
$25 X-6,100-101$
\end{tabular} & & $\begin{array}{l}\text { 10R-1, 30-31 } \\
\text { 10R-5, 32-33 }\end{array}$ & $\begin{array}{c}11 \mathrm{H}-5,140-141 \\
12 \mathrm{H}-6,34-36\end{array}$ & $\begin{array}{c}12 \mathrm{R}-1,39-40 \\
15 \mathrm{R}-1,36-37 \\
\end{array}$ & & \\
\hline & & NN3 & CN2 & & 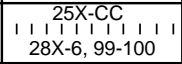 & & $\begin{array}{c}\text { 10R-CC } \\
11 \mathrm{R}-1,47-48 \\
\end{array}$ & $\begin{array}{l}12 \mathrm{H}-7,34-36 \\
13 \mathrm{H}-4,34-36 \\
\end{array}$ & (insufficient data) & & \\
\hline & $\frac{\gtrsim}{\grave{্}}$ & NN2 & & c & 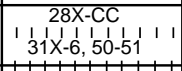 & (no data) & $11 R-3,57-58$ & $\begin{array}{l}13 \mathrm{H}-5,130-131 \\
13 \mathrm{H}-7,34-36\end{array}$ & 15R-CC & & Orthorhabus serratus * \\
\hline & (1) & NN1 & CN1 & b & $31 \mathrm{X}-\mathrm{CC}$ & & $\begin{array}{c}11 \mathrm{R}, \mathrm{CC} \\
\text { 12R-2, 73-74 }\end{array}$ & $14 \mathrm{H}-2,34-36$ & & & Discoaster druggii \\
\hline $\begin{array}{r}\text { la } \\
\text { Oli }\end{array}$ & & & & a & 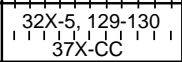 & & & & & & Acme C. abisectus \\
\hline & & NN25 & CP19 & & $38 X-1,107-109$ & & 12R-2, 94-95 & $14 \mathrm{H}-3,34-36$ & & & \\
\hline
\end{tabular}

- First appearance datum/ lowest occurrence in cores. $\square$ Hiatus: no sediments or very condensed section.

$\checkmark$ Last appearance datum/highest occurrence in cores. ?? Questionable stratigraphic breaks.

* Primary event for recognition of (sub) zonal 111 Barren interval: sediments devoid of calcareous nannofossils;
vertical extent is inherently uncertain. boundary, where paired events are indicated.

Figure 2. Calcareous nannofossil biostratigraphic summary of the upper Cenozoic on the Côte d'Ivoire-Ghana Marginal Ridge, Leg 159. 
sils, with only traces of Coccolithus pelagicus, Cyclicargolithus abisectus and Discoaster deflandrei, whereas the two higher samples (159-959A-32X-2, 119-120 cm, and 32X-1, 120-121 cm), are totally barren of calcareous nannofossils.

Similarly, the boundary between Subzones CN1b and CN1c is in an impoverished/barren interval. Sample 159-959A-29X-6, 100-101 $\mathrm{cm}$, is almost barren of calcareous nannofossils, with only traces of Coccolithus eopelagicus and nondescript discoasters, while Samples 159-959A-29X-5, 99-100 cm, and 29X-4, 97-98 cm, are totally barren of calcareous nannofossils. Core 159-959A-29X is principally a nannofossil chalk with clay, diatomite, and radiolarians. Assemblages of Subzone CN1c were identified in the interval from Samples 159959A-29X-3, 52-53 cm, through 28X-CC, based on the presence of Orthorhabdus serratus. An intervening sample (159-959A-29X-1, $88-89 \mathrm{~cm}$ ) is virtually barren of calcareous nannofossils, with only traces of discoasters (D. deflandrei 'group').

Assemblages in Samples 159-959A-28X-6, 99-100 cm, through 25X-CC, contain the marker species for the Miocene Zone CN2, Sphenolithus belemnos, in association with Orthorhabdus serratus, Helicosphaera ampliaperta, H. scissura, H. obliqua, Triquetrorhabdulus carinatus, Discoaster deflandrei, D. nephados, Cyclicargolithus floridanus, and Reticulofenestra lockeri. Sample 159-959A$28 \mathrm{X}-3,101-102 \mathrm{~cm}$, in the lower part of this zone, is barren of calcareous nannofossils, and Sample 28X-4, 100-101 cm, contains traces only of $O$. serratus, ?H. ampliaperta, C. floridanus, Coronocyclus nitescens, and D. deflandrei.

Lower Miocene Zone CN3, characterized by the co-occurrence of Sphenolithus heteromorphus and Helicosphaera ampliaperta, occurs in Samples 159-959A-25X-6, 100-101 cm, through 21X-1, 100-101 $\mathrm{cm}$. Assemblages are poorly to moderately preserved, with abundant unidentifiable nannofossil debris occurring in some; evidence of strong dissolution was observed in a few samples. Several species of Helicosphaera (including $H$. scissura, $H$. obliqua, $H$. mediterranae, $H$. intermedia, and $H$. euphratis) occur sporadically within this zone. Discoaster petaliformis has its lowest occurrence in the upper part of the zone.

Zone CN4 assemblages from Samples 159-959A-20X-7, 35-36 $\mathrm{cm}$, through $19 \mathrm{H}-5,100-101 \mathrm{~cm}$, are generally moderately preserved, but signs of dissolution were observed in several of these assemblages, often accompanied by abundant unidentifiable nannofossil debris. Key species present include Sphenolithus heteromorphus, Discoaster petaliformis, Cyclicargolithus floridanus, Discoaster sanmiguelensis, and Triquetrorhabdulus milowii; both Helicosphaera ampliaperta and Triquetrorhabdulus rugosus are absent.

Samples 159-959A-19H-4, 100-101 cm, and 19H-3, 100-101 $\mathrm{cm}$, above good assemblages of Zone CN4, are barren of calcareous nannofossils. Sample 159-959A-19H-2, 100-101 cm, below good assemblages of Zone CN5, contains an impoverished assemblage consisting of a few corroded specimens of Helicosphaera carteri, Reticulofenestra pseudoumbilicus, Coccolithus miopelagicus, C. pelagicus, fragments of ?Discoaster sanmiguelensis, and Discoaster $\mathrm{sp}$. cf. D. variabilis. Immediately below this largely barren/impoverished interval (glauconitic clay beds within a clayey nannofossil chalk unit), Discoaster petaliformis, Cyclicargolithus floridanus, and circular Coronocyclus nitescens, together with Sphenolithus heteromorphus, had their highest occurrences, probably suggesting a truncated $\mathrm{CN} 4$ and/or a reduced Zone CN5 above the barren interval. Elsewhere, both $C$. floridanus and D. petaliformis are known to disappear within Zone CN5, the $\mathrm{HO}$ of $C$. floridanus being well above the $\mathrm{HO}$ of $D$. petaliformis (see, for example, Perch-Nielsen, 1985; de Kaenel and Villa, 1996)

Subzone CN5a is indicated by assemblages containing Discoaster sanmiguelensis, D. exilis, and Triquetrorhabdulus rugosus, and lacking Discoaster kugleri, in Samples 159-959A-19H-1, 100-101 cm, through $18 \mathrm{H}-5,100-101 \mathrm{~cm}$. The successive appearances of the key species Discoaster kugleri, Catinaster coalitus, Discoaster hamatus, and Catinaster calyculus upsection in the interval comprising Samples 159-959A-18H-3, 100-101 cm, through $15 \mathrm{H}-6,100-101 \mathrm{~cm}$, enabled recognition of Subzone CN5b, Zone CN6, and Subzones CN7a and CN7b (Table 1). Discoaster bollii has its HO in Sample 159-959A-15H-6, 100-101 cm. Most assemblages in the interval of Zones CN5-CN7 contain abundant unidentified nannofossil debris, and show evidence of mild dissolution.

Assemblages from Samples 159-959A-15H-5, 100-101 cm, through 14H-4, 100-101 cm, contain Minylitha convalis, Discoaster pentaradiatus, D. calcaris, D. variabilis, and Triquetrorhabdulus rugosus. Both Discoaster berggrenii and D. quinqueramus, which occur above, are absent, as are Discoaster hamatus, D. bollii and Catinaster spp. which are present below. This indicates the upper Miocene Subzone CN8b. An unconformity is detected between Samples 159-959A-15H-6, 100-101 cm (Subzone CN7b), and 15H-5, 100$101 \mathrm{~cm}$ (Subzone CN8b): Subzone CN8a is missing. In Sample 159959A-15H-5, 100-101 cm, a few specimens of Cruciplacolithus tenuis and Gartnerago obliquum were found, suggesting reworking from Paleocene and Cretaceous sources.

The interval of Samples 159-959A-14H-3, 100-101 cm, through $9 \mathrm{H}-6,100-101 \mathrm{~cm}$, contains assemblages assignable to the upper Miocene Zone CN9. Abundant Discoaster berggrenii and Minylitha convalis occur consistently in Samples 159-959A-14H-3, 100-101 $\mathrm{cm}$, through 159-959A-13H-3, 100-101 cm, indicating Subzone CN9a. Amaurolithus spp. occur sporadically with consistent Discoaster quinqueramus, affirming assignment to Subzone CN9b of Samples 159-959A-13H-1, 100-101 cm, through 9H-6, 100-101 cm. Amaurolithus delicatus occurs in more samples than any of the other Amaurolithus spp.; each of A. primus, A. amplificus, and A. tricorniculatus occurs only once within Subzone CN9b. A gap of about $13 \mathrm{~m}$ occurs between the $\mathrm{HO}$ of $M$. convalis and the LO of A. delicatus.

Assemblages from Samples 159-959A-9H-5, 100-101 cm, through $8 \mathrm{H}-2,100-101 \mathrm{~cm}$, are assigned to Zone CN10, primarily because (a) they occur immediately above the HO of Discoaster quinqueramus, which is in Sample 159-959A-9H-6, 100-101 cm; (b) Amaurolithus tricorniculatus is present in the highest sample (Sample 159-959A-8H-2, 100-101 cm); and (c) Ceratolithus spp. are occasionally present in the interval. Species of both the genera Amaurolithus and Ceratolithus are sparse, and our determination of the CN10c/CN11a boundary and subdivision of Zone CN10 (Fig. 2) are tentative.

The top of lower Pliocene Zone CN11 is usually drawn at the extinction of Reticulofenestra pseudoumbilicus and Sphenolithus spp. (S. neoabies and S. abies). These two events are well separated in Hole 959A; assemblages in Samples 159-959A-6H-1, 100-101 cm, through 5H-6, 100-101 cm, lack $R$. pseudoumbilicus, but include $S$. neoabies and S. abies. Recognition of the base of Subzone CN11b was based on the LO of typical Pseudoemiliania lacunosa in Sample 159-959A-6H-2, 100-101 cm, where the lowest common occurrence of $D$. asymmetricus is also determined. This justifies the use of the former event as a proxy for the latter in sections where the acme of D. asymmetricus is difficult to determine.

Upper Pliocene Zone CN12 in Samples 159-959A-5H-4, 100$101 \mathrm{~cm}$, through $3 \mathrm{H}-3,100-101 \mathrm{~cm}$, is based on the association of Discoaster brouweri, Helicosphaera sellii and Pseudoemiliania lacunosa, in the absence of Sphenolithus neoabies, S. abies, and Reticulofenestra pseudoumbilicus. Subdivision of this zone was made possible by successive HOs of Discoaster tamalis, D. surculus, and D. pentaradiatus.

Assemblages in Samples 159-959A-3H-2, 100-101 cm, through 2H-CC, contain Pseudoemiliania lacunosa, Helicosphaera sellii, Calcidiscus macintyrei, and Gephyrocapsa aperta. These indicate the lower Pleistocene Subzone CN13a. Gephyrocapsa caribbeanica and P. lacunosa co-occur in Samples 159-959A-2H-7, 100-101 cm, 
through 1H-4, 100-101 cm, without the association of Gephyrocapsa oceanica, indicating Subzone CN13b.

Assemblages in Samples 159-959A-2H-2, 100-101 cm, through 2H-1, 100-101 cm, contain Gephyrocapsa oceanica, G. caribbeani$c a$, a small species of Gephyrocapsa (including G. aperta), Pseudoemiliania lacunosa, and Florisphaera profunda. This association indicates lower Pleistocene Subzone CN14a.

Nannofossils indicative of upper Pleistocene Zone CN15, including Emiliania huxleyii, medium sized Gephyrocapsa species (G. caribbeanica and G. oceanica), Calcidiscus leptoporus, and Umbilicosphaera sibogae, were found in Sample 159-959A-1H-1, 50-51 $\mathrm{cm}$. This zone could not be consistently identified because of difficulty in identifying the very small E. huxleyii using optical microscopy where the species is not dominant. Sample 159-959A-1H-2, 100-101 $\mathrm{cm}$, with questionable E. huxleyii, is assigned to the combined zonal interval of $\mathrm{CN} 15$ and $\mathrm{CN} 14 \mathrm{~b}$.

\section{Hole 959B (Water Depth 2090.2 m)}

Only part of the section sampled in Hole 959A was cored in Hole 959B, with coring extending only down to the middle Miocene in Core 159-959B-20H.

The distribution of nannofossil species in Hole 959B is indicated in Table 2, without estimates of their relative abundances. It is similar to that in Hole 959A (see above) and need not be discussed in detail, except to affirm some important points: (1) a barren interval lies between the assemblages of Zones CN4 and CN5 (dark glauconitic clay beds within a clayey nannofossil chalk unit; Samples 159-959B-20H$1,59-61 \mathrm{~cm}$, and $19 \mathrm{H}-6,59-61 \mathrm{~cm}$, are without calcareous nannofossils, and Sample 159-959B-19H-CC contains only traces of Discoaster spp.); (2) the base of this barren interval coincides with the tops of the stratigraphic ranges of Sphenolithus heteromorphus, Discoaster petaliformis, and Cyclicargolithus floridanus; (3) immediately above the barren interval, a change in the populations of Coronocyclus nitescens occurs (circular variety has its $\mathrm{HO}$ and oval variety has its LO in Sample 159-959B-19H-5, 59-61 cm); (4) the LO of oval Coronocyclus nitescens is at about the same level as the HO of Orthorhabdus serratus, in Subzone CN5b; (5) Catinaster calyculus is scarce, with concomitant uncertainty in locating the base of Subzone CN7b; (6) assemblages assignable to Subzone CN8a are missing, and the top of Subzone CN7b is probably truncated, as suggested by the disappearance of both Discoaster hamatus and D. bollii at the same level, immediately below the LO of Minylitha convalis; (7) most of the middle Miocene sediments and the lower part of the upper Miocene section are condensed, being relatively thin; (8) large Reticulofenestra pseudoumbilicus disappears in the interval from mid-Subzone CN8b to within Subzone CN9b; (9) species of Amaurolithus and Ceratolithus are sparse in Zone CN10, making it difficult to subdivide this zone and to precisely locate the CN10/CN11 boundary; (11) small gephyrocapsids (including Gephyrocapsa aperta) are present below the Pleistocene, notably as a "bloom" within Zone CN11, in association with abundant small Pseudoemiliania lacunosa; (12) Sphenolithus neoabies and S. abies range higher than the $\mathrm{HO}$ of Reticulofenestra pseudoumbilicus, at the CN11/CN12 boundary; and (13) Florisphaera profunda, present at the top of the Pleistocene section, ranges intermittently down to within the upper Miocene Subzone $\mathrm{CN9b}$

\section{Hole 960A (Water Depth 2048.3 m)}

Rotary drilling in this hole severely disturbed the Pleistocene and Pliocene parts of the sequence, where core recovery rates never exceeded one section per core. In the Miocene part, recovery rates im- proved, averaging 4 sections per core. Most of the Miocene and Pliocene (sub)zones were recognized (Fig. 2; Table 3). A succession of subzones indicating middle to early late Miocene ages were identified in a single core, indicating a very condensed middle upper Miocene section. Four hiatuses are recognized within this section.

Nannofossils assignable to upper Oligocene Subzone CP19b, with Sphenolithus ciperoensis, are in Sample 159-960A-12R-2, 94 $95 \mathrm{~cm}$. Basal Miocene Subzone CN1b occurs immediately above, in Sample 159-960A-12R-2, 73-74 cm, indicating an unconformity at the top of the Oligocene in this hole. Subzone CN1b is based on the association of Cyclicargolithus floridanus, Discoaster saundersii, D. nephados, D. druggii (small form), and Triquetrorhabdulus carinatus, in the absence of Orthorhabdus serratus. The latter species occurs in Sample 159-960A-11R-3, 57-58 cm, indicating Subzone CN1c. Helicosphaera ampliaperta has its LO in Sample 159-960A12R-1, 120-121 cm (in Subzone CN1b).

Sphenolithus belemnos in Samples 159-960A-11R-1, 47-48 cm, and 10R-CC, indicates Zone CN2. Sphenolithus heteromorphus, together with Helicosphaera ampliaperta, in Samples 159-960A-10R$5,32-33 \mathrm{~cm}$, through $10 \mathrm{R}-1,30-31 \mathrm{~cm}$, indicate Zone CN3. The HO of $S$. belemnos is in Sample 159-960A-10R-CC, below the LO of $S$. heteromorphus. The top of Zone CN3 is indicated at the LO of Helicosphaera ampliaperta in Sample 159-960A-10R-1, 30-31 cm. Sphenolithus heteromorphus ranges upward through Samples 159960A-9R-CC and 9R-2, 140-141 cm, indicating lower middle Miocene Zone CN4. Assemblages in Core 159-960A-9R are not confined to Zone CN4, but include upper Miocene Subzone CN9a (see Table 3).

Samples 159-960A-9R-2, $110 \mathrm{~cm}$, and 9R-2, $90 \mathrm{~cm}$, contain common Catinaster coalitus, C. mexicana, and Discoaster bollii. This association, in the absence of Discoaster hamatus, characterizes middle Miocene Zone CN6. An unconformity is evident between Samples 159-960A-9R-2, 140-141 cm (Zone CN4), and 159-960A-9R-2, 110 $\mathrm{cm}$ (Zone CN6): the top of Zone CN4 is probably truncated, Zone CN5 is missing, and Zone CN6 is very thin (less than $1 \mathrm{~m}$ in thickness). Truncation of the top of Zone CN4 (Sample 159-960A-9R-2, $140-141 \mathrm{~cm})$ is suggested because the species Coronocyclus nitescens, Cyclicargolithus floridanus, Discoaster deflandrei, and Triquetrorhabdulus milowii all have their HOs simultaneously at the level of the unconformity. Consistent with the absence of Zone CN5 and a thin Zone CN6 is the absence of Coccolithus miopelagicus at the unconformity. The base of Zone CN6 contains evidence of mixing and/or reworking; several older species (such as Reticulofenestra lockeri, Sphenolithus heteromorphus, and Triquetrorhabdulus carinatus, derived from Zone CN4 and older sediments) are present in Sample 159-960A-9R-2, $110 \mathrm{~cm}$. A reduced Zone CN6 is also indicated by the LOs of both Discoaster sanmiguelensis and D. exilis being at its base.

Subzone CN7a was not identified, and the assemblage in a sample a few centimeters above the top of Zone CN6 (i.e., Sample 159960A-9R-2, 60-61 cm) contains Discoaster hamatus, D. bollii, and D. pseudovariabilis, in association with Catinaster calyculus, C. coalitus and $C$. mexicana, indicating Subzone CN7b. Similarly, Subzone CN8a was not identified, and the assemblage in a sample a few centimeters above the top of Subzone CN7b (i.e., Sample 159-960A9R-1, 29-30 cm), contains Minylitha convalis, Discoaster neorectus, $D$. calcaris, D. surculus, and D. pentaradiatus, indicating Subzone $\mathrm{CN} 8 \mathrm{~b}$. Once more the pattern is being repeated, Subzone CN9a was not identified, and the assemblage in a sample, a few centimeters above Subzone CN8b (i.e., Sample 159-960A-9R-1, 3-4 cm), contains abundant Discoaster quinqueramus and very rare Amaurolithus delicatus, but lacks Minylitha convalis, indicating Subzone CN9b. The virtual absence of Discoaster berggrenii from Subzone CN9b, particularly from its basal part (Table 3), is consistent with the absence of Subzone CN9a. Discoaster quinqueramus ranges through- 
out Subzone CN9b, and its HO (at the top of the subzone) is in Sample 159-960A-7R-3, 130-131 cm. This indicates that Subzone CN9b is about $16 \mathrm{~m}$ thick, which contrasts sharply with the underlying thin upper Miocene divisions (the combined Subzone CN7b and CN6 is less than $2.5 \mathrm{~m}$ thick).

Species of Amaurolithus are rare and sporadic in Subzone CN9b. An isolated occurrence of common Minylitha convalis in Subzone CN9b (Sample 159-960A-8R-CC), is difficult to explain.

Recognition of Subzone CN10b was based on rare Ceratolithus armatus and C. acutus in Sample 159-960A-6R-CC, above the HO of both Triquetrorhabdulus rugosus and T. farnsworthii. Species of Amaurolithus co-occur with Ceratolithus rugosus in the short interval of Samples 159-960A-6R-1, 104-105 cm, through 6R-1, 10-11 $\mathrm{cm}$, indicating lower Pliocene Subzone CN10c. This is unlike the record in Hole 960C, where Amaurolithus spp. were not found with C. rugosus, and separation of Subzones CN11a and CN10c was not possible. Consistent occurrences of rare Discoaster asymmetricus in Samples 159-960A-6R-1, 34-35 cm, and 6R-1, 10-11 cm, make identification of the rarely used Subzone CN10d (Bukry, 1981) seem possible.

Lower Pliocene Zone CN11 assemblages were identified in Cores 159-960A-5R and 4R. In these assemblages, Discoaster asymmetricus is rare or even absent, but becomes common in Samples 159960A-4R-1, 50-52 cm, and 159-960A-3R-CC, above the HO of Reticulofenestra pseudoumbilicus. Typical $(>5 \mu \mathrm{m}$, circular) Pseudoemiliania lacunosa has its LO in Sample 159-960A-4R-1, 50-52 $\mathrm{cm}$, indicating Subzone CN11b. Both Sphenolithus neoabies and S. abies have their HO in Sample 159-960A-3R-CC. The assemblages in Section 159-960A-4R-1 contain abundant small Gephyrocapsa spp. (including $G$. aperta). This is about the same level as the Pliocene 'bloom' of small Gephyrocapsa spp. at Site 959.

Assemblages of Zone CN12 were identified in Core 159-960A3R. Subzone CN12a, in Sample 159-960A-3R-1, 100-101 cm, contains Discoaster asymmetricus, D. brouweri, D. pentaradiatus, D. surculus, D. tamalis, Helicosphaera sellii, and small Pseudoemiliania lacunosa. A similar association, minus both $D$. tamalis and $D$. asymmetricus, was identified a few centimeters above (Sample 159960A-3R-1, 95-96 cm), indicating Subzone CN12b. Both Discoaster brouweri and D. pentaradiatus occur in Sample 159-960A-3R-1, 7$8 \mathrm{~cm}$, together with normal sized P. lacunosa, H. sellii, and Florisphaera profunda, indicating Subzone CN12c. The apparent absence of Subzone CN12d (Fig. 2) is probably an artifact of inadequate sampling and very poor core recovery. Sample 159-960A-2R-CC lacks the large to medium-sized Gephyrocapsa spp. (G. caribbeanica and G. oceanica) as well as Discoaster spp., and contains Calcidiscus macintyrei, Helicosphaera sellii, P. lacunosa, and Florisphaera profunda, suggesting lower Pleistocene CN13a. Assemblages from the top of the hole in Core 159-960A-1R are assigned to lower Pleistocene Subzone CN14a. This is based on the presence of Gephyrocapsa oceanica, G. caribbeanica, Helicosphaera inversa, Umbilicosphaera sibogae, Pseudoemiliania lacunosa, and small Gephyrocapsa spp.

\section{Hole 960C (Water Depth 2034.9 m)}

Core recovery in this hole contrasted sharply with that from Hole $960 \mathrm{~A}$, being $100 \%$ in the upper Cenozoic sequence. The distribution of nannofossil species in this hole (Table 4) is generally similar to that in Hole 960A. Differences are minor, largely attributable to sampling and the general rarity of several key species, particularly the amaurolithids and ceratolithids. The middle Miocene and lower upper Miocene section is thick and broken by four unconformities.

An assemblage assignable to the basal Miocene Subzone CN1b was recovered from Sample 159-960C-14H-2, 34-36 cm. This is strongly etched and impoverished and contains common to frequent Cyclicargolithus floridanus, small Discoaster druggii, D. saundersii,
Triquetrorhabdulus carinatus, Reticulofenestra lockeri, and rare $C y$ clicargolithus abisectus. Neither Orthorhabdus serratus nor Discoaster druggii (15 $\mu \mathrm{m}$ or more) are present. Nannofossils from immediately below in Sample 159-960C-14H-3, 34-36 cm, are indicative of the upper Oligocene Subzone CP19b, with Sphenolithus ciperoensis, Helicosphaera truempyi, and common Cyclicargolithus abisectus being present. Subzone CN1a is missing, and an unconformity at the top of the Oligocene is deduced.

Samples 159-960C-14H-1, 34-36 cm, and 13H-CC, are barren of calcareous nannofossils. This barren interval separates the impoverished assemblage in Sample 159-960C-14H-2, 34-36 cm (Subzone CN1b), from abundant, moderately well preserved assemblage in Sample 159-960C-13H-7, 34-36 cm (Subzone CN1c).

Helicosphaera ampliaperta occurs in conjunction with several other species in Samples 159-960C-13H-7, 34-36 cm, through $11 \mathrm{H}-$ 5, 140-141 cm: (1) with Orthorhabdus serratus in Samples 159960C-13H-7, 34-36 cm, through 13H-5, 130-131 cm, indicating lower Miocene Subzone CN1c; (2) with Zone CN2 marker Sphenolithus belemnos in Samples 159-960C-13H-4, 34-36 cm, through $12 \mathrm{H}-7,34-36 \mathrm{~cm}$; and (3) with S. heteromorphus in Sample 159960C-12H-6, 34-36 cm, through 11H-5, 140-141 cm, indicating lower Miocene Zone CN3. Chiasmolithus solitus was found in Sample $159-960 \mathrm{C}-12 \mathrm{H}-3,130-131 \mathrm{~cm}$, indicating minor reworking. Abundant Sphenolithus heteromorphus, Cyclicargolithus floridanus, Reticulofenestra pseudoumbilicus, Discoaster sanmiguelensis, D. exilis, and Helicosphaera carteri/kamptneri in Sample 159-960C-11H4, 34-36 cm, through $10 \mathrm{H}-7,34-36 \mathrm{~cm}$, indicate middle Miocene Zone CN4.

The stratigraphic ranges of several species (Coccolithus miopelagicus, Discoaster petaliformis, Discoaster sanmiguelensis, Cyclicargolithus floridanus, circular Coronocyclus nitescens, together with Sphenolithus heteromorphus) appear truncated at the top of Zone CN4 in Sample 159-960C-10H-7, 34-36 cm. In the same sample, reworking is evident in the presence of the undeniable (rare Eocene) Chiasmolithus solitus. The overlying assemblage, in Sample 159-960C-10H-6, 34-36 cm, is assigned to Zone CN6, based on the occurrence of frequent Catinaster coalitus, rare C. mexicana, together with common Discoaster bollii, D. exilis, and D. variabilis, and the absence of $D$. hamatus. A substantial hiatus is indicated: Zone $\mathrm{CN} 4$ is truncated, Zone CN5 is missing, and Zone CN6 is reduced.

Both Discoaster hamatus and D. bollii are present, along with very rare Catinaster calyculus, in Samples 159-960C-10H-5, 34-36 $\mathrm{cm}$, and $10 \mathrm{H}-4,34-36 \mathrm{~cm}$, indicating upper Miocene Subzone CN7b. Subzone CN7a is missing.

Samples 159-960C-10H-3, 34-36 cm, through 9H-7, 64-65 cm, contain consistent Minylitha convalis, Discoaster pentaradiatus, $D$. neohamatus, D. calcaris, and D. variabilis, as well as sporadic $D$. neorectus, D. loeblichii, and Triquetrorhabdulus rugosus, indicating upper Miocene Subzone CN8b. Subzone CN8a is missing.

Assemblages in Samples 159-960C-9H-6, 34-36 cm, through 8H$5,130-131 \mathrm{~cm}$, are assignable to upper Miocene Subzone CN9b; Subzone CN9a is missing. In these assemblages Discoaster quinqueramus is common and consistent in distribution, but $D$. berggrenii and species of Amaurolithus are rare, occurring sporadically. There is virtually no gap between the HO of Minylitha convalis in Sample 159-960C-9H-7, 64-65 cm, and the LO of Amaurolithus spp. (in this case A. bizzarus) in Sample 9H-6, 34-36 cm.

Subzone CN10a, in Samples 159-960C-8H-3, 130-131 cm, and $8 \mathrm{H}-1,130-131 \mathrm{~cm}$, was recognized by the presence of Triquetrorhabdulus rugosus and/or T. farnsworthii in the absence of Discoaster quinqueramus. Subzone CN10b was identified in Samples 159-960C-7H-CC through 159-960C-7H-5, 130-131 cm; the assemblage in the upper sample is particularly noteworthy because of the presence of rare Ceratolithus armatus, Amaurolithus bizzarus, and Discoaster asymmetricus. Assemblages in the overlying interval, comprising Samples 159-960C-7H-1, 130-131 cm, through 5H-5, 
$130-131 \mathrm{~cm}$, are broadly assigned to the combined Subzones CN10c/ CN11a. These assemblages contain Ceratolithus rugosus, Discoaster brouweri, D. pentaradiatus, D. surculus, $R$. pseudoumbilicus, $S$. neoabies, and S. abies, without any species of Amaurolithus. Discoaster asymmetricus is virtually absent, being present only in the lowermost sample of the interval, Sample 159-960C-7H-1, 130-131 cm. A small oval form of P. lacunosa and small Gephyrocapsa spp. occur in the uppermost sample of this interval (i.e., Sample 159-960C-5H$5,130-131 \mathrm{~cm})$. Subzone CN11b is indicated by the presence of common Discoaster asymmetricus, Pseudoemiliania lacunosa, Sphenolithus neoabies, S. abies, and frequent D. tamalis in Samples 159-960C-5H-3, 129-130 cm, through 4H-5, 130-131 cm. Reticulofenestra pseudoumbilicus is absent from Samples 159-960C-4H$\mathrm{CC}$ and $4 \mathrm{H}-5,130-131 \mathrm{~cm}$, but occurs in Core 159-960C-5H and below. Small Gephyrocapsa species (including G. aperta) occur abundantly in the assemblages of Subzone CN11b.

Upper Pliocene Zone CN12 was identified in the interval comprising Samples 159-960C-4H-3, 130-131 cm, through 2H-CC, with all its subzones being represented. Assemblages readily assignable to Subzone CN12a occur in samples from Core 159-960C-4H. These contain Discoaster tamalis, D. brouweri, D. pentaradiatus, Calcidiscus macintyrei, C. leptoporus, Helicosphaera sellii, Pseudoemiliania lacunosa, and Florisphaera profunda, without Reticulofenestra pseudoumbilicus, Sphenolithus neoabies, or S. abies.

Lower Pleistocene Zone CN13 occurs in Samples 159-960C-2H$6,35-37 \mathrm{~cm}$, through $2 \mathrm{H}-3,10-11 \mathrm{~cm}$, and could easily be subdivided. The assemblage in Sample 159-960C-2H-6, 35-37 cm, contains Calcidiscus macintyrei, Helicosphaera sellii, Pseudoemiliania lacunosa, and Florisphaera profunda, and is assigned to Subzone CN13a. Assemblages in Samples 159-960C-2H-5, 10-11 cm, and $2 \mathrm{H}-3,10-11 \mathrm{~cm}$, contain Gephyrocapsa caribbeanica, without $G$. oceanica, indicating Subzone CN13b. The Samples 159-960C-2H-1, $10-11 \mathrm{~cm}$, through $1 \mathrm{H}-5,29-30 \mathrm{~cm}$, contain C. leptoporus, G. oceanica, G. caribbeanica, F. profunda, Umbilicosphaera sibogae, and $P$. lacunosa, which indicate Subzone CN14a. A similar association of species, but minus $P$. lacunosa and with the addition of both ?Emiliania huxleyii and $U$. irregularis, occurs in Samples 159-960C-1H-3, $30-31 \mathrm{~cm}$, through $1 \mathrm{H}-1,17-19 \mathrm{~cm}$. Identification of E. huxleyii is somewhat uncertain, but suggests the interval of Subzone CN14b and Zone CN15.

\section{Hole 961A (Water Depth 3292 m)}

Core recovery from the upper Cenozoic section in this hole, particularly the Miocene part, was very poor, hence the apparent stratigraphic breaks in Figure 2. In most of the Miocene section, each core is confined to a single zone (or even subzone).

Sample 159-961A-15R-CC contains an assemblage indicative of Subzone CN1c. In this assemblage, Orthorhabdus serratus, small Discoaster druggii, Sphenolithus compactus, S. dissimilis, D. deflandrei, D. adamanteus, Coronocyclus nitescens, and several species of the genus Helicosphaera are present. Sample 159-961A-16R-CC lacks calcareous nannofossils, but contains a lower Miocene radiolarian fauna. The first downhole sample with calcareous nannofossils (Sample 159-961A-17R-CC) contains an association of species indicative of the early Eocene age (Shafik et al., Chap. 32, this volume).

The interval comprising Samples 159-961A-15R-1, 36-37 cm, through 11R-CC, contains assemblages characterized by the presence of the key species Sphenolithus heteromorphus, (Zones CN3 and CN4); Zone CN2 was not identified. Assemblages in the lower samples (Samples 159-961A-15R-1, 36-47 cm, through 12R-1, 39$40 \mathrm{~cm}$ ) include $H$. ampliaperta, indicating Zone CN3. The Zone CN4 assemblage in Sample 159-961A-11R-CC is impoverished and almost barren of nannofossils, having a few specimens of Cyclicargolithus floridanus, Reticulofenestra pseudoumbilicus, Discoaster sanmiguelensis, D. exilis, and Helicosphaera kamptneri. Core 159961A-10R had no recovery.

Main elements of the assemblages in Core 159-961A-9R include Discoaster hamatus, D. bollii, D. calcaris, D. variabilis, Catinaster coalitus, C. mexicana, Triquetrorhabdulus rugosus, and Calcidiscus macintyrei, together with rare Catinaster calyculus, indicating upper Miocene Subzone CN7b.

Core 159-961A-8R contains abundant, well-preserved nannofossils including Minylitha convalis, Discoaster pentaradiatus, D. neohamatus, D. calcaris, D. variabilis, and Triquetrorhabdulus rugosus, but lacks Discoaster hamatus, D. bollii, D. berggrenii, and species of Catinaster. This association indicates upper Miocene Subzone CN8b. The longer Subzone CN8a is not represented in this hole; a likely hiatus separates Cores 159-961A-9R and 8R.

Well-preserved assemblages of upper Miocene Zone CN9 were identified in Cores 159-961A-7R through 5R. Those in Samples 159961A-5R-CC through 6R-CC contain several extremely rare but undeniable species of Amaurolithus (mainly represented by either $A$. primus or A. delicatus), and are assigned to Subzone CN9b. Species of Amaurolithus are absent in Sample 159-961A-7R-CC, but Minylitha convalis is present instead, in association with abundant Discoaster berggrenii and D. quinqueramus, indicating Subzone CN9a. Discoaster asymmetricus was found in Sample 159-961A-6R-CC.

Core 159-961A-4R contains assemblages indicative of Zone CN10. Rare Amaurolithus delicatus in Sample 159-961A-4R-1, 89$91 \mathrm{~cm}$, together with rare Ceratolithus rugosus, Discoaster asymmetricus, and Helicosphaera sellii suggests Subzone CN10c: A. delicatus is the only species of Amaurolithus found in Core 159-961A-4R, and only in one sample; D. asymmetricus occurs at lower levels, in Zone CN9, and could not be used to indicate Subzone CN10d.

Well-preserved assemblages, assignable to the lower Pliocene Subzone CN11b, occur in Core 159-961A-3R. These contain Reticulofenestra pseudoumbilicus, Sphenolithus neoabies, S. abies, and Pseudoemiliania lacunosa: R. pseudoumbilicus and S. neoabies are present up to Sample 159-961A-3R-2, 34-35 cm; S. abies persists up to Sample 3R-1, 34-35 cm. Discoaster asymmetricus occurs in most of the core, but $P$. lacunosa is more common, appearing first (upsection) in the core-catcher sample. The seeming absence of Subzone CN11a is probably an artifact of inadequate sampling.

Core $159-961 \mathrm{~A}-2 \mathrm{R}$ recovered only a $4-\mathrm{cm}$ section (in the corecatcher). This yielded an assemblage with Discoaster tamalis, D. pentaradiatus, and $D$. brouweri, indicative of mid-Pliocene Subzone CN12a. The assemblage in Sample 159-961A-1R-CC lacks discoasters, and contains an association indicative of lower Pleistocene Subzone CN13a: Pseudoemiliania lacunosa, Helicosphaera sellii, Florisphaera profunda, Calcidiscus macintyrei, and C. leptoporus. The assemblage in Sample 159-961A-1R-1, 3-5 cm, is dominated by Emiliania huxleyii, Gephyrocapsa oceanica, G. caribbeanica, and Florisphaera profunda, indicating Zone CN15. The Pleistocene section is condensed, being about $3.4 \mathrm{~m}$ thick (Core 159-961A-1R), and probably contains a hiatus.

\section{Hole 962B (Water Depth $4637 \mathrm{~m}$ )}

Site 962 is on a minor ridge associated with the Côte d'IvoireGhana marginal ridge. Upper Cenozoic calcareous nannofossil-bearing sediments in Hole 962B are restricted to a thin, predominantly barren, Pliocene and upper Pleistocene section (the upper three cores), which overlies a much thicker section entirely barren of calcareous nannofossils (the underlying six cores). This section recalls the general pattern of deposition on the main ridge during the Paleogene: a nannofossil-bearing sequence interrupted by episodes of noncalcareous deposition, condensed sedimentation or stratigraphic gaps, overlying a thick section barren of calcareous nannofossils (Shafik et al., Chap. 32, this volume). 
There is a significant lithologic change between Cores 159-962B$3 \mathrm{H}$ and $4 \mathrm{H}$, separating zeolitic clay (below) from nannofossil clay (above). A few specimens of Discoaster pentaradiatus, Sphenolithus abies, Reticulofenestra pseudoumbilicus, and $R$. minutula were found in Sample 159-962B-4H-1, 50-52 cm. Except for this, samples from Cores 159-962B-4H through 159-962B-9H are barren of calcareous nannofossils. Albian nannofossils were found in Core 159-962B$10 \mathrm{H}$.

The interval comprising Samples 159-962B-3H-CC and 159962B-3H-3, 50-52 cm, contains assemblages indicative of lower Pliocene Subzone CN11a. These include Discoaster asymmetricus, D. brouweri, D. penraradiatus, Ceratolithus rugosus, Reticulofenestra pseudoumbilicus, Sphenolithus neoabies, and S. abies. Intervening Samples 159-962B-3H-6, 51-53 cm, and 3H-5, 50-52 cm, are barren of calcareous nannofossils. Sample 159-962B-3H-2, 50-52 $\mathrm{cm}$, contains abundant, moderately well-preserved nannofossils. These include Pseudoemiliania lacunosa, Sphenolithus neoabies, and $S$. abies, but not R. pseudoumbilicus, indicating the upper part of Subzone CN11b. Sample 159-962B-3H-1, 130-131 cm, lacks calcareous nannofossils, and Sample $3 \mathrm{H}-1,53-55 \mathrm{~cm}$, contains abundant, moderately well-preserved nannofossils indicative of upper Pliocene Subzone 12b. These include Discoaster brouweri, D. pentaradiatus, D. surculus, Calcidiscus macintyrei, C. leptoporus, Helicosphaera sellii, and Pseudoemiliania lacunosa. Sample 159-962B-2H-CC contains rare, poorly preserved nannofossils lacking Discoaster spp. and including instead Gephyrocapsa caribbeanica, G. aperta, and G. margerellii, indicating lower Pleistocene Subzone CN13b.

In the barren interval between Subzones CN11b and CN12b, concentrations of glauconite were identified as hardgrounds, based on lithologic criteria (see Mascle, Lohmann, Clift et al., 1996). A long hiatus is identified between Samples $159-962 \mathrm{~B}-3 \mathrm{H}-1,53-55 \mathrm{~cm}$, and $2 \mathrm{H}-\mathrm{CC}$ because of the absence of Subzones CN12c, CN12d, and CN13a.

Sample 159-962B-2H-7, 50-52 cm, is barren of calcareous nannofossils. Samples 159-962B-2H-6, 50-52 cm, and 2H-5, 50-52 cm, contain assemblages of variable preservation. Main elements of these assemblages include Gephyrocapsa oceanica and G. caribbeanica, with Pseudoemiliania lacunosa indicating lower Pleistocene Subzone CN14a. In Sample 159-962B-2H-5, 50-52 cm, trace amounts of reworked Eocene taxa (e.g., Chiasmolithus solitus) were found. No calcareous Eocene sediments of Eocene age were cored at the site, although they are known from the shallower Sites 959 and 960.

The interval comprising Samples 159-962B-2H-3, 130-131 cm, through $2 \mathrm{H}-1,50-52 \mathrm{~cm}$, is barren of calcareous nannofossils. In contrast, Sample 159-962B-1H-CC contains abundant, moderately well preserved nannofossils including G. aperta, G. oceanica, G. caribbeanica and Helicosphaera inversa, indicating upper Pleistocene Subzone CN14b. Sample 159-962B-1H-5, 78-80 cm, is barren, but abundant, moderately well preserved nannofossils occur in Sample 1H-4, 133-134 cm. These are dominated by G. oceanica and G. caribbeanica. Samples 159-962B-1H-4, 50-52 cm, through 1H-3, $130-131 \mathrm{~cm}$, are barren of calcareous nannofossils, and only a residual assemblage was found in Sample 159-962B-1H-3, 96-97 cm. This consists mainly of G. omega, G. caribbeanica, C. leptoporus, and Helicosphaera carteri, indicating upper Pleistocene Subzone CN14b. Rare, strongly etched nannofossils mostly of $G$. omega and $F$. profunda occur in Sample 159-962B-1H-2, 25-26 cm. The assemblage in Sample 159-962B-1H-1, 1-2 cm, is strongly affected by dissolution, but is assignable to Zone CN15. It contains Emiliania huxleyii, Calcidiscus leptoporus, Ceratolithus sp., Umbilicosphaera sibogae, Florisphaera profunda, and several species of Gephyrocapsa, including $G$. omega and $G$. oceanica, in addition to reworked Calci- discus macintyrei. Most specimens are severely etched, and only the gephyrocapsids and $F$. profunda are relatively abundant.

\section{BIOSTRATIGRAPHIC SUMMARY AND REMARKS}

Sediment accumulation rates for the Neogene sequences on the Côte d'Ivoire-Ghana marginal ridge (Mascle, Lohmann, Clift, et al., 1996) suggest a relatively more expanded sequence at Site 959, on the shoulder of the ridge, compared with that at Site 960, on the crest of the ridge. Sites 960 and 961 were sediment-starved during much of the Neogene, receiving much less sediment and having more hiatuses than was the case at Site 959. Species ranges at Site 959 are longer than at the other two sites, with the attendant result that a gap between a pair of $\mathrm{HO}$ and LO events at Site 959 may not exist at the other two sites. The relationship between the HO of Sphenolithus belemnos and the LO of Sphenolithus heteromorphus discussed below is a case in point.

\section{Oligocene/Miocene Transition}

The Oligocene/Miocene boundary occurs at a disconformity at Site 960, and within a barren interval at Site 959: the uppermost Oligocene Subzone CN1a is missing at Site 960; while the end of acme of Cyclicargolithus abisectus (top of Oligocene/Subzone CN1a), was reasonably distinct, being immediately below a barren interval in Hole 959A.

\section{Lower Miocene}

We use the LO of Orthorhabdus serratus as the primary determinant of the base of Subzone CN1c, rather than the LO of the poor stratigraphic indicator Discoaster druggii. Originally, both D. druggii and $O$. serratus were included in the definition of the $\mathrm{CN} 1 \mathrm{~b} / \mathrm{CN} 1 \mathrm{c}$ subzonal boundary (see Bukry, 1973), but the former species was ranked as the primary criterion, being perceived as more cosmopolitan. Problems in determination of the LO of D. druggii (e.g., because the species is overgrown with calcite or rare) have necessitated combining Subzones CN1b with CN1c, but occasionally a substitute was used (see, for example, Olafsson, 1989, who also used the LO of $O$. serratus in nearby Hole 667A). On the Côte d'Ivoire-Ghana marginal ridge, a small form of $D$. druggii occurs well below the LO of $O$. serratus and the normal sized $(>15 \mu \mathrm{m}) D$. druggii is very rare. It is worthy of note that in Berggren et al. (1995b) the numerical age of the LOs of $O$. serratus and D. druggii is the same, based on both events occurring at the same level in Hole 516F.

In our material, the LO of Orthorhabdus serratus is close to the equally distinct LO of Geminilithella rotula. In the Mediterranean region, where the LO of $G$. rotula was first used in biostratigraphy, it was recognized above the LO of $O$. serratus-between the LO of Helicosphaera ampliaperta (below), and the LO of Sphenolithus heteromorphus (above) (see Theodoridis, 1984).

The LO of Sphenolithus belemnos (base of Zone CN2) is a sharp, easily identifiable event in sections on the Côte d'Ivoire-Ghana marginal ridge. Evidence from elsewhere is emerging to suggest that this event is very useful in correlation, and probably is synchronous over low- and mid-latitude areas (see Fornaciari et al., 1990, 1993; Olafsson, 1991; Fornaciari and Rio, 1996).

Sphenolithus heteromorphus occurs consistently over its range on the Côte d'Ivoire-Ghana marginal ridge, and its LO (base of Zone CN3) is easily detectable. In Hole 959A, there is a gap between the $\mathrm{HO}$ of Sphenolithus belemnos and the LO of Sphenolithus hetero- 
morphus. But in Hole 960A, there is virtually no gap between these two levels. The HO of Helicosphaera ampliaperta (top of Zone CN3) is a neat, easily identifiable event. Most of the assemblages of Zone $\mathrm{CN} 3$ are characterized by common $H$. ampliaperta, and abundant $S$. heteromorphus.

\section{Middle and Upper Miocene}

The HO of Sphenolithus heteromorphus (top of Zone CN4) is a sharp event, and is probably truncated at Sites 959 and 960. This event is immediately below an unconformity at Site 960. At Site 959, it is immediately below the base of a barren interval where other species have their highest occurrences as well. At Site 961, Zone CN4 was identified in almost barren sediments.

The LO of Discoaster kugleri is used to identify the base of Subzone CN5b, although the species in Hole 959B is very rare and sporadic in its lower range, because of a lack of any other, clearer, event in the interval of Zone CN5. The HO of Cyclicargolithus floridanus, which was suggested originally by Bukry (1973) as a possible alternative event to the LO of $D$. kugleri, is probably only a short distance above the top of Zone CN4 at low latitudes (see Raffi et al., 1995) or above the LO of D. kugleri at middle latitudes (Site 139: Roth and Thierstein, 1972). In any case, at Site 959 , the HO of $C$. floridanus coincides with the base of a barren interval, which is immediately below Zone CN5 assemblages. The HO of Coronocyclus nitescens, along with the HO of Orthorhabdus serratus, are considered to be good biostratigraphic events, useful for subdividing the Zone CN5 interval (see Raffi et al., 1995). This is partially supported in this study. At Site 959, two varieties of $C$. nitescens were distinguished, a circular variety (the typical form), and an oval one. Both varieties were found together in one sample only, at the base of Zone CN5, with the oval variety disappearing higher within Subzone CN5b. The $\mathrm{HO}$ of oval $C$. nitescens is very close to the $\mathrm{HO}$ of $O$. serratus in both Holes 959A and 959B, but the range of $O$. serratus is disjunct. In Hole 959A, this species is virtually absent in Zones CN3 and CN4, and its upper range is short. Such a distribution pattern, although not unknown for other species (e.g., Isthmolithus recurvus in southern Australia; Shafik, 1996) may lend itself to interpretation of reworking (i.e., the upper range of the species may be considered displaced occurrences). However, the distribution pattern of $O$. serratus in equatorial eastern Pacific Holes 575B, 806B, 845B, and 846D and at tropical Indian ocean Site 714 (as shown in Raffi et al., 1995; Raffi and Flores, 1995) is not dissimilar to that at Site 959, in that the species is absent in the interval of Zones CN4 and CN3. At Site 289 in equatorial western Pacific, the reappearance of $O$. serratus in the section is in Zone CN5, and after a short, continuous range, it disappears abruptly in the upper part of Zone CN5 (data in Shafik, 1975). More documentation of the stratigraphic range of $O$. serratus is needed to ascertain its biostratigraphic potential, including the species LO at the base of Subzone CN1c, the zonal CN3-CN4 gap in its range, and its $\mathrm{HO}$ in upper Zone CN5 (or as a possible approximation of the top of Subzone CN5a).

Catinaster coalitus is consistent throughout its range at Sites 959 and 960. Its LO (the base of Subzone CN6) is a sharp, easily identifiable event. Similarly, the LO of Discoaster hamatus (the base of Subzone CN7) is an easily detectable event, but the LO of Catinaster calyculus (the base of Subzone CN7b) was determined only tentatively because the species is scarce. This is generally true for all events based on rare species at Site 959.

Evidence is mounting to suggest that the $\mathrm{LO}$ of $C$. calyculus is at or below the LO of Discoaster hamatus (Peleo-Alampay and Wei, 1995; Raffi et al., 1995). Nevertheless, the distribution of both spe- cies in Holes 959A and 959B is in agreement with Bukry's (1973, 1975 ) results, indicating that the LO of $C$. calyculus is younger than the LO of $D$. hamatus. This is very important because detection of the hiatus immediately above Zone CN6 at Site 960 (Fig. 2) hinges on the LO of $C$. calyculus being above the LO of D. hamatus.

The upper Miocene Subzone CN8a is missing in all sections cored on the Côte d'Ivoire-Ghana marginal ridge, and recognition of Subzone $\mathrm{CN} 8 \mathrm{~b}$ was based primarily on consistent occurrences of $\mathrm{Mi}$ nylitha convalis without the association of Discoaster bollii, or D. berggrenii. Bukry (1973) used the LO's of D. neorectus and D. loeblichii to indicate the base of Subzone CN8b. Both species are rare, only intermittently occurring in the upper Miocene of the Côte d'Ivoire-Ghana marginal ridge. Also, D. bellus was not found, but this is not inconsistent with the absence of its name-bearing subzone (the $D$. bellus Subzone of Bukry, 1973), and probably suggests a reduced Subzone CN8b.

The LO of Discoaster quinqueramus is well above the LO of $D$. berggrenii at Site 959, but at Site 960,D. quinqueramus occurs at the base of Zone CN9, without D. berggrenii. This is consistent with Subzone CN9a being missing at Site 960.

Amaurolithids are rare in the upper Miocene and Pliocene on the Côte d'Ivoire-Ghana marginal ridge, occurring mostly intermittently. This is true in Zone CN9. We use the HO of Minylitha convalis as a proxy for the LO of Amaurolithus primus, which defines the base of Subzone CN9b, to determine the top of Subzone CN9a at Site 959. At nearby Site 667, on the Sierra Leone Rise, amaurolithids are also rare, as indicated by Manivit (1989), who estimated the amaurolithid/ total assemblage ratio there to be $<1: 10,000$; with this low abundance, the LO of $A$. primus may easily escape detection. Minylitha convalis is usually common to abundant throughout its stratigraphic range, making its $\mathrm{HO}$ easy to determine. However, A. primus (or Amaurolithus spp. in general) may be rare and sporadic near the base of its stratigraphic range. Relying on the LO of Amaurolithus spp., without regard to the $\mathrm{HO}$ of $M$. convalis, can lead to discrepancies in age determination and uncertainties in correlation. Gartner (1992) assigned an age of about 6.4 Ma to the LO of species of Amaurolithus at mid-latitude North Atlantic Site 608, while acknowledging that it has a significantly older age at lower latitudes. In its lower range at Site 608, Amaurolithus spp. are rare. In contrast, $M$. convalis has a good top at the same site, to which Gartner (1992) assigned an age of 6.7 Ma.

One argument against the biostratigraphic use of Minylitha convalis is that it is often overlooked or confused with Florisphaera profunda, which ranges down into the upper Miocene. Raffi et al. (1995) questioned the reliability of the $\mathrm{HO}$ of $M$. convalis for long-distance correlations, while conceding some of the problems in precisely locating the LO of Amaurolithus primus.

The HO of Discoaster quinqueramus (top Zone CN9) may be difficult to determine. Near this level the species develops spurs at its tips, and becomes somewhat similar to a variety of $D$. pentaradiatus, which has very small bifurcations at the tips and is common at about the same level. Under crossed nicols, however, the two can be separated, with $D$. pentaradiatus being partially birefringent, showing a characteristic figure.

\section{Upper Miocene Interval Without Reticulofenestra pseudoumbilicus}

The upper Miocene record on the Côte d'Ivoire-Ghana marginal ridge shows large (>7 $\mu \mathrm{m}$ ) Reticulofenestra pseudoumbilicus temporarily disappearing during the interval from (?mid) Subzone CN8b to within Subzone CN9b. Concomitant with this disappearance is a notable increase in the abundance of small placoliths, which probably 
include small Gephyrocapsa spp.: the smaller species of Reticulofenestra, particularly $R$. minuta, dominate the reticulofenestrids after a seemingly initial sharp decline in its abundance. This distribution pattern of reticulofenestrids is particularly evident at Site 959, but is also discernible, though less clearly, in the condensed sections at Site 960.

Only in recent studies has the upper Miocene interval without Reticulofenestra pseudoumbilicus been given prominence (Rio et al., 1990a, Gartner, 1992; Raffi and Flores, 1995), even though it can be discerned in distribution charts of earlier studies (e.g., Shafik, 1975). The reason for its recently acquired prominence is the realization that it occupies the same stratigraphic position (Zone CN8-CN9) across the three principal oceans (Raffi et al., 1995; this study), obviously with important oceanographic and biostratigraphic implications. The interval has been identified mainly in low-latitude sections. Rio et al. (1990a) described the interval (their R. pseudoumbilicus paracme) from four eastern tropical Indian Ocean sites, and Raffi and Flores, (1995) recorded it (their absence interval of $R$. pseudoumbilicus) at eight sites in the eastern equatorial Pacific. Based on distribution charts in Shafik (1975), the interval is also detectable in the western equatorial Pacific, at the Ontong Java Plateau Site 289, the same stratigraphic position (mid-Zone CN8 to within Subzone CN8b) as Site 959.

In the mid-latitude North Atlantic Site 608, Gartner (1992) identified the base of the interval at an abrupt size decrease in the reticulofenestrids, and interpreted it as a major change in productivity. We accept that the interval was a high-productivity event.

Correlation of the interval without $R$. pseudoumbilicus to magnetostratigraphy (Raffi et al., 1995) indicates that it extends from the upper part of Chron 4An to the lower part of Chron 3Ar, which, in terms of the timescale of Berggren et al. (1995b), spans about 2 m.y. (from about $8.8 \mathrm{Ma}$ to about $6.8 \mathrm{Ma}$ ).

\section{Pliocene}

Ceratolithids are rare in the Pliocene and Pleistocene on the Côte d'Ivoire-Ghana marginal ridge, occurring mostly intermittently. In the lowermost Pliocene assemblages, they are dominated by Ceratolithus armatus rather than C. acutus. The base of Subzone CN10b, approximating the Miocene/Pliocene boundary, is relatively easy to determine, but only by using the combination of the LO of Ceratolithus armatus/acutus and the $\mathrm{HO}$ of Triquetrorhabdulus rugosus. In Hole 959A, Ceratolithus rugosus is virtually absent above the HO of $R$. pseudoumbilicus, and its presence below the HO of Amaurolithus spp. allowed determination of Subzone CN10c. Manivit (1989) indicated that $C$. rugosus is rare at the nearby Sites 658-659, making it difficult to determine the base of Zone NN13 (Subzone CN10c).

The HO of amaurolithids, marking the top of Subzone CN10c, could not always be identified with confidence in this study. In Hole 960C, Subzones CN10c and CN11a could not be differentiated because Amaurolithus spp. were not detected above the LO of Ceratolithus rugosus. At ODP Leg 108 sites to the west of the Côte d'IvoireGhana marginal ridge, amaurolithids are never common, and are even less numerous toward the end of their ranges; it is therefore difficult to recognize the zonal boundary CN10/CN11 (Manivit, 1989).

Discoaster asymmetricus occurs in the upper Miocene on the Côte d'Ivoire-Ghana marginal ridge, and its occurrences in the Pliocene below the $\mathrm{HO}$ of Amaurolithus spp. are intermittent and could not be used for identification of Subzone CN10d of Bukry (1986). In Hole 960C, this species is virtually absent from the combined Subzones $\mathrm{CN} 10 \mathrm{c} / \mathrm{CN} 11 \mathrm{a}$ interval, although it is common above, in Subzone CN11b, and occurs sporadically below, in Subzones CN8b through CN10b. At Sites 665 and 666, D. asymmetricus is rare or even absent below the HO of R. pseudoumbilicus (Manivit, 1989) and, similarly, could not be used reliably to mark the base of Zone NN14 (or Subzone CN10d).
The top of Zone CN11 is usually drawn at the HOs of Reticulofenestra pseudoumbilicus and Sphenolithus spp. (S. abies and $S$. neoabies), the former event being the primary criterion (see Bukry, 1973). These two events are well separated in all Pliocene sections on the Côte d'Ivoire-Ghana marginal ridge. A similar sequence was recorded to the west of the ridge, in the eastern equatorial Atlantic, at Sites 659, 660, 661 and 662 (Manivit, 1989) and elsewhere (see, for example, Gartner et al., 1987; Rio et al., 1990b). A period of $150 \mathrm{k} . \mathrm{y}$. separated the two events (Berggren et al., 1995a). We use the HO of $S$. abies and $S$. neoabies in preference to the $\mathrm{HO}$ of $R$. pseudoumbilicus for recognition of the top of Zone CN11. In its upper stratigraphic range, $R$. pseudoumbilicus reaches its minimum size, and often becomes difficult to differentiate from a large $R$. minutula; some researchers choose $5 \mu \mathrm{m}$ as the species minimum length (e.g., Young, 1990; Gartner, 1992), while others choose a longer minimum length (e.g., >5-6 $\mu \mathrm{m}$, Backman and Shackleton, 1983; >7 $\mu \mathrm{m}$, Raffi and Rio, 1979; Fornaciari et al., 1990). Size variation in both S. abies and S. neoabies toward the end of their ranges is not a cause of confusion; these species are the only representatives of their genus in the midPliocene.

The beginning of the acme of Discoaster asymmetricus was identified in between the HOs of Amaurolithus spp. (below) and of $R$. pseudoumbilicus (above), when it was first used by Bukry (1973) to subdivide Zone CN11. At Sites 959 and 960, the lowest common $D$. asymmetricus is very close to the HO of $R$. pseudoumbilicus, below the HO of Sphenolithus spp. (S. neoabies and S. abies), suggesting that the beginning of the acme of $D$. asymmetricus is diachronous. In the area immediately to the west of the Côte d'Ivoire-Ghana marginal ridge, Manivit (1989) reported a similar distribution pattern for $D$. asymmetricus at Sites 665 and 666. The LOs of small (>5 $\mu \mathrm{m}$, oval) Pseudoemiliania lacunosa, Discoaster tamalis, typical P. lacunosa (circular, $<5 \mu \mathrm{m}$ ), and common $D$. asymmetricus are very close in Zone CN11 at Sites 959 and 960. The LO of typical P. lacunosa was easier to determine than the lowest common D. asymmetricus at Site 961, suggesting the former is a more useful biostratigraphic marker.

A normal succession of Pliocene discoasters permitted easy recognition of the subzones of Zone CN12 at Sites 959 and 960, although both Discoaster pentaradiatus and D. surculus were particularly rare towards the end of their indicated ranges.

\section{Mid-Pliocene Interval of Small Gephyrocapsa}

An interval with abundant small placoliths, characteristically including $<3.5-\mu \mathrm{m}$ gephyrocapsids, is recognizable within midPliocene Zone CN11 at Sites 959, 960, 961, and elsewhere. At nearby Site 366, on the Sierra Leone Rise, small gephyrocapsids have been recorded in Zone CN11 (Samtleben, 1980). At low-latitude sites in the western Indian Ocean, abundant gephyrocapsids have been recognized as confined to a distinct short interval within Zone CN11 (Young, 1990). At middle latitudes, however, more than one acme interval of Pliocene small gephyrocapsids has been described (Driever, 1988). Our Zone CN11 interval of small gephyrocapsids probably correlates with Subzone NN14-15B of Driever (1988) in the Mediterranean region, which corresponds to the middle of his lower long interval of dominance of gephyrocapsids (this subzone contains Sphenolithus spp. and Reticulofenestra pseudoumbilicus, without Amaurolithus spp., the latter being present in the underlying Subzone NN14-15A; Driever, 1988).

Concentrations of small gephyrocapsids have also been recorded in other parts of the upper Cenozoic. Upper Miocene gephyrocapsids have been recorded in association with abundant small placoliths, at mid-latitude sites in the North Atlantic Ocean (Gartner, 1992; de Kaenel and Villa, 1996); these are confined to a short interval within Zone CN9. A possible low-latitude correlative with this middle-latitude acme of small placoliths is the upper Miocene interval without large Reticulofenestra pseudoumbilicus recognized at Sites 959 and 
960. As discussed above, this interval contains abundant small placoliths, which may include small Gephyrocapsa spp. In the Pleistocene, dominance of small gephyrocapsids (the so-called small $G e$ phyrocapsa Zone of Gartner, 1977) occurs within a short interval in Subzone CN14a. This is the best-known interval of dominance of small gephyrocapsids; it has been recorded more widely than the older ones.

Gartner (1992) suggested that the upper Miocene acme of small placoliths at middle latitude signal an important change in surfacewater properties that enhance productivity. Earlier, Driever (1988) showed that acmes of small gephyrocapsids in Pliocene sections in the Mediterranean coincide with intervals when surface water temperatures were relatively low. The geographic scale of these changes in surface waters must have been wide to account for the numerous occurrences of abundant small gephyrocapsids. Small gephyrocapsids (and associated small placoliths) are easily overlooked, and more work is needed to determine properly their geographic distribution in pre-Pleistocene sections, especially at low latitudes. This would ultimately help in determining whether these low-latitude occurrences are synchronous.

\section{Pleistocene}

The HO of typical Pseudoemiliania lacunosa is a distinct, easily identified event compared with the LO of Emiliania huxleyii, and it was necessary to combine Zone CN15 with Subzone CN14b, where gephyrocapsids and not E. huxleyii dominate the assemblage. Smalland medium-sized gephyrocapsids are abundant in the Pleistocene on the Côte d'Ivoire-Ghana marginal ridge, and the populations of Gephyrocapsa oceanica and G. caribbeanica are easily separated.

In the absence of both Discoaster brouweri and G. caribbeanica (the criteria defining the limits of the short Subzone CN13a), the association of Helicosphaera sellii, and Calcidiscus macintyrei was used as evidence for recognition of Subzone CN13a.

Common to abundant Florisphaera profunda occurs in most Pleistocene samples of Site 959 and 960. Florisphaera profunda ranges down into the upper Miocene at Sites 959 and 960, similar to its range in equatorial Pacific Site 289 (see Okada, 1983).

\section{MIOCENE HIATUSES}

In oceanic sections, a hiatus may not only be recognized by a discontinuity in ages, but also by an abrupt decrease in average sediment accumulation rates below that typical for the sediment type recovered in the interval (Rona, 1973). In this study, hiatuses were detected at breaks in the nannofossil biostratigraphic sequence, and condensed sections were identified where average sediment accumulation rates are relatively low. A break or a hiatus in the nannostratigraphic sequence is most likely to be easily recognized where a whole (sub)zone or a number of (sub)zones are missing, but not necessarily where only parts of (sub)zones are missing. In studies employing two or more integrated stratigraphic systems (see, for example, Keller and Barron, 1983; Aubry, 1995), the cumulative stratigraphic resolution may allow detection of short hiatuses, equivalent to a part of a subzone.

In Figure 2, most stratigraphic breaks, which fall between cores, are considered questionable, because such breaks are likely to be a result of incomplete core recovery rather than hiatuses (see also Moore et al., 1978). This is exemplified by the two breaks in the PliocenePleistocene section in Hole 960A (see Fig. 2), where core recovery was exceedingly poor (1.2 $\mathrm{m}$ of sediment recovered from a cored interval of $18.7 \mathrm{~m}$ ). These two breaks have no counterparts in Hole $960 \mathrm{C}$, where core recovery was almost complete.

\section{The Miocene Record on the Côte d'Ivoire-Ghana Marginal Ridge}

The Miocene section (about $210 \mathrm{~m}$ thick) at Site 959, on the shoulder of the Côte d'Ivoire-Ghana marginal ridge, is more than three times the thickness of its counterpart (less than $60 \mathrm{~m}$ thick) at Site 960 on the crest of the ridge; the latter is largely condensed. Preservation of calcareous microfossils in the lower Miocene units (diatomite interbedded with nannofossil chalk, clayey chalk, and clays) at Site 959 is highly variable, with barren and nannofossil-bearing beds alternating. The youngest barren interval lies between nannofossil assemblages of Zones CN4 and CN5. This suggests repeated episodes of severe carbonate dissolution during much of the early and middle Miocene. Earlier, during the late Paleogene, a similar sedimentation history at the site also resulted in the formation of alternating non-calcareous (biosiliceous) and calcareous (nannofossil-bearing) sediments (Shafik et al., Chap. 32, this volume). In most of the middle and upper Miocene units (nannofossil ooze/chalk) at Site 959, preservation of calcareous microfossils is generally poor, with abundant unidentifiable nannofossil debris, as well as evidence of partial dissolution of recognizable nannofossil specimens. This part of the section contains a hiatus which corresponds to the upper Miocene Subzone CN8a. Sediments marking the end of this hiatus were found to contain evidence of minor reworking from Cretaceous and Paleocene sources.

The largely condensed Miocene contains four hiatuses in its middle and upper parts and one barren interval in its lowermost part (Fig. 2). The temporal extent of these hiatuses are shown in Figure 3. The only Miocene hiatus present at Site 959 (CN8a hiatus), is present also at Site 960, and probably in Hole 961 A as well. Evidence of very minor reworking from Eocene sources was found at the erosional surface marking the start (probably late Zone CN4) and the end (probably within Zone CN6) of the CN5 hiatus. This hiatus partly corresponds with the barren interval between Zones CN4 and CN5 at Site 959.

\section{The Sierra Leone Rise and Nearby Sites}

Data combined from Olafsson (1989) and Manivit (1989) suggest that the middle Miocene CN5 hiatus, which was identified on the crest of the Côte d'Ivoire-Ghana marginal ridge (Sites 960), is detectable at nearby Site 667 on the Sierra Leone Rise. There, Olafsson (1989) recorded the LO of S. heteromorphus (top of Zone CN4) in Sample 108-667A-18H-1, 135-136 cm, and Manivit (1989) showed that the LO of Catinaster coalitus (base of Zone CN6) is immediately above, in Sample 108-667A-17H-CC. This suggests a regional extent for this middle Miocene hiatus.

The interval corresponding to the late Miocene CN7a hiatus through the late Miocene CN8a hiatus at Site 960 has no diagnostic species (except perhaps for Discoaster pentaradiatus), and contains evidence of reworking (Coronocyclus nitescens, Cyclicargolithus floridanus, and Helicosphaera granulata) at Site 667 (based on data in Manivit, 1989). In nearby Hole 366A, also on the Sierra Leone Rise, Bukry (1977) recorded Subzone CN7b immediately above Zone CN6 and immediately below Zone CN9. Although this may be a good indication of a condensed section, it cannot be taken as clear evidence for the absence of Subzone CN7a and Zone CN8 because Bukry (1977) based his study largely on one sample per core. Interestingly, data in Manivit (1989) present more compelling evidence for the absence of Subzone CN7a in Hole 659A to the north of Site 366.

It appears from the above discussion that the middle and upper Miocene section on the Sierra Leone Rise is largely condensed; Zone CN5 is absent at Site 667 and Subzones CN7a and CN8a were not recorded at either Sites 336 or 667 , while at the latter site, evidence for a reworking episode was identified. 
Figure 3. Sea-level curve, Neogene oceanic hiatuses and the upper Cenozoic on the Côte d'Ivoire-Ghana marginal ridge, Leg 159. In the sea-level curve column, figures between brackets are total sea-level falls in meters. Note the strong correlation between the $\mathrm{CN} 7 \mathrm{a}$ hiatus, CN8a hiatus, and CN9a hiatus on the ridge, and the $\mathrm{NH} 3, \mathrm{NH} 4$ and $\mathrm{NH} 5$, respectively.

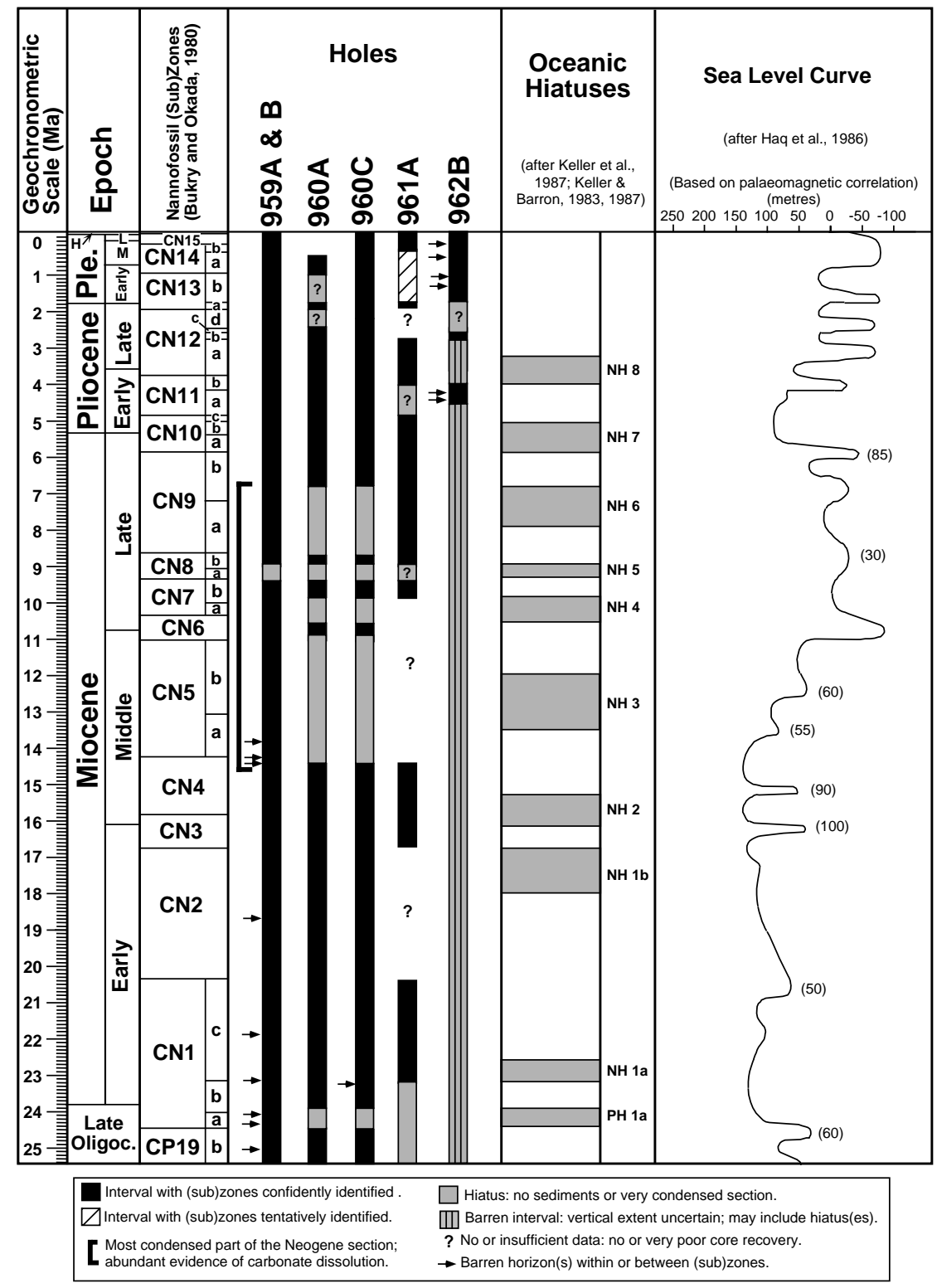

\section{Correlation with Deep-Sea Hiatuses}

recorded a succession of biohorizons in a single core (Core 108661A-10H) indicative of upper Miocene Subzones CN7b through CN9a, above a barren interval in the same core: top of barren interval in Sample 108-661A-10H-4, $140 \mathrm{~cm}$; Subzone CN7b in Samples 108-661A-10H-4, 45-46 cm, and 108-661A-10H-3, 150-151 cm; Subzone CN8a in Sample 108-661A-10H-3, 130-131 cm; Subzone CN8b in Sample 108-661A-10H-1, 110-111 cm; and Subzone CN9a in Sample 108-661A-10H-1, 70-71 cm. In contrast, all of the overlying core (Core 108-661A-9H) is assigned to Subzone CN9b. Minylitha convalis was not recorded by Manivit (1989), but it is still reasonable to suggest that the $\sim 5$-m-thick upper Miocene section (representing Subzones CN7b through to CN9a) is condensed. Subzone $\mathrm{CN9a}$ is particularly thin, and the rate of accumulation for the combined Zone CN8 and Subzone CN9a, is <0.8 per 1 m.y. (using the timescale of Berggren et al., 1995b), suggesting a possible hiatus.
As shown in Figure 3, the middle and late Miocene hiatuses, defour described by Keller and Barron (1983, 1987; see also Keller et al., 1987). According to Keller and Barron (1983), these Neogene hiatuses coincided with climatic cooling, sea level falls, and increased carbonate dissolution. Evidence of pronounced carbonate dissolution in the middle and lower upper Miocene section on the ridge have already been noted above, and Figure 3 seems to support a correlation between the hiatuses and falls in sea level. The CN5 hiatus on the crest of the ridge (Site 960) is longer than NH3, but seems to coincide with a period of progressively lowering global sea level, with two major sea level falls (a 55-m drop followed by a 60-m drop). The CN5 hiatus probably began as an erosional event which left rare Eocene nannofossils at Site 960 and terminated with the deposition tected on the Côte d'Ivoire-Ghana marginal ridge, correspond with 
of reworked nannofossils from Zone CN4 and older sediments at the same site. Modern deep-current circulation probably was established by the time of this hiatus. The CN7a hiatus at Site 960, which corresponds well with NH4 of Keller and Barron $(1983,1987)$, was probably a consequence of the drastic sea level fall (a 125-m drop) that occurred late in Zone CN6 time.

The CN8a hiatus, on different parts of the Côte d'Ivoire-Ghana marginal ridge, neatly fits with the well-documented, widespread NH5 of Keller and Barron (1983, 1987). The erosional intensity of this event, which was probably greater than any other hiatus during the middle and late Miocene (Keller and Barron, 1983), is evident at Site 959 where reworked Cretaceous and Paleocene nannofossils were found in the sediments marking its termination. The CN9a hiatus at Site 960 may have started earlier than the NH6 of Keller and Barron $(1983,1987)$, but both probably terminated at about the same time. Coincidently with this hiatus is the high-productivity event that temporarily eliminated large Reticulofenestra pseudoumbilicus from low-latitude areas.

Interestingly, Figure 3 shows that both the CN5 hiatus and CN8a hiatus began at the highs on the sea-level curve and ended at the lows, whereas the CN7 a hiatus began at a low on the curve, and ended at a high and the CN9a hiatus began and ended at lows on the sea-level curve.

\section{CONCLUSIONS}

An almost complete upper Cenozoic sequence of nannofossil (sub)zones was identified in Hole 959A, with proxies for the rare marker species being employed. Only Subzone CN8a was missing, but this subzone was also missing from other holes on the ridge, indicating a widespread hiatus off the Côte d'Ivoire and Ghana. Three other hiatuses were recognized in the largely condensed middle and upper Miocene section at Site 960. During the oldest of these hiatuses a series of short episodes of increased dissolution of calcareous microfossils and an influx of siliceous fossils at Site 959 ended. The four hiatuses correlate well with other oceanic hiatuses known in three principal oceans, and coincide roughly with major falls in global sea level.

\section{ACKNOWLEDGMENTS}

We thank both Marie-Pierre Aubry (Institut des Sciences de l'Evolution, Universite Montpellier II, France) and Wuchang Wei (Scripps Institute of Oceanography, University of California) for their constructive criticism of this paper. The senior author thanks N.F. Exon (Australian Geological Survey Organisation, Canberra) for his helpful review of an earlier draft of the manuscript. This paper is published with the permission of the Executive Director of the Australian Geological Survey Organisation, Canberra.

\section{REFERENCES}

Aubry, M.-P., 1995. From chronology to stratigraphy: interpreting the lower and middle Eocene stratigraphic record in the Atlantic Ocean. In Berggren, W.A., Kent, D.V., Aubry, M.-P., and Hardenbol, J. (Eds.), Geochronology, Time Scales, and Global Stratigraphic Correlation: A Unified Temporal Framework for an Historical Geology. Spec. Publ.-Soc. Econ. Palaeontol. Mineral., 54:213-274.

Backman, J., and Shackleton, N.J., Quantitative biochronology of Pliocene and Early Pleistocene calcareous nannoplankton from the Atlantic, Indian and Pacific Oceans. Mar. Mircopaleontol. 8:141-170.

Berggren, W.A., Hilgen, F.J., Langereis, C.G., Kent, D.V., Obradovich, J.D., Raffi, I., Raymo, M.E., and Shackleton, N.J., 1995a. Late Neogene chro- nology: new perspectives in high-resolution stratigraphy. Geol. Soc. Am. Bull., 107:1272-1287.

Berggren, W.A., Kent, D.V., Swisher, C.C., III, and Aubry, M.-P., 1995b. A revised Cenozoic geochronology and chronostratigraphy. In Berggren, W.A., Kent, D.V., Aubry, M.-P., and Hardenbol, J. (Eds.), Geochronology, Time Scales and Global Stratigraphic Correlation. Spec. Publ-Soc. Econ. Paleontol. Mineral., 54:129-212.

Bramlette, M.N., and Wilcoxon, J.A., 1967. Middle Tertiary calcareous nannoplankton of the Cipero Section, Trinidad, W.I. Tulane Stud. Geol., 5:93-132.

Bukry, D., 1973. Low-latitude coccolith biostratigraphic zonation. In Edgar, N.T., Saunders, J.B., et al., Init. Repts. DSDP, 15: Washington (U.S. Govt. Printing Office), 685-703.

1975. Coccolith and silicoflagellate stratigraphy, northwestern Pacific Ocean, Deep Sea Drilling Project Leg 32. In Larson, R.L., Moberly, R., et al., Init. Repts. DSDP, 32: Washington (U.S. Govt. Printing Office), 677-701.

, 1978. Cenozoic coccolith and silicoflagellate stratigraphy, offshore northwest Africa, Deep Sea Drilling Project Leg 41. In Lancelot, Y., Seibold, E., et al., Init. Repts. DSDP, 41: Washington (U.S. Govt. Printing Office), 689-707.

1981. Pacific coast coccolith stratigraphy between Point Conception and Cabo Corrientes, Deep Sea Drilling Project Leg 63. In Yeats, R.S., Haq, B.U., et al., Init. Repts. DSDP, 63: Washington (U.S. Govt. Printing Office), 445-471.

de Kaenel, E., and Villa, G., 1996. Oligocene-Miocene calcareous nannofossils biostratigraphy and paleoecology from the Iberia Abyssal Plain. In Whitmarsh, R.B., Sawyer, D.S., Klaus, A., and Masson, D.G. (Eds.), Proc. ODP, Sci. Results, 149: College Station, TX (Ocean Drilling Program), 79-145.

Driever, B.W.M., 1988. Calcareous nannofossil biostratigraphy and paleoenvironmental interpretation of the Mediterranean Pliocene. Utrecht Micropalaeontol. Bull., 26:1-245.

Fornaciari, E., Backman, J., and Rio, D., 1993. Quantitative distribution patterns of selected lower to middle Miocene calcareous nannofossils from the Ontong Java Plateau. In Berger, W.H., Kroenke, L.W., Mayer, L.A., et al., Proc. ODP, Sci. Results, 130: College Station, TX (Ocean Drilling Program), 245-256.

Fornaciari, E., Raffi, I., Rio, D., Villa, G., Backman, J., and Olafsson, G., 1990. Quantitative distribution patterns of Oligocene and Miocene calcareous nannofossils from the western equatorial Indian Ocean. In Duncan, R.A., Backman, J., Peterson, L.C., et al., Proc. ODP, Sci. Results, 115: College Station, TX (Ocean Drilling Program), 237-254.

Fornaciari, E., and Rio, D., 1996. Latest Oligocene to early middle Miocene quantitative calcareous nannofossil biostratigraphy in the Mediterranean region. Micropaleontology, 42:1-36.

Gartner, S., 1969. Correlation of Neogene planktonic foraminifer and calcareous nannofossils zones. Trans. Gulf Coast Assoc. Geol. Soc., 19:585599.

, 1977. Calcareous nannofossil biostratigraphy and revised zonation of the Pleistocene. Mar. Micropaleontol., 2:1-25.

, 1992. Miocene nannofossil chronology in the North Atlantic, DSDP Site 608. Mar. Micropaleontol., 18: 307-331.

Gartner, S., Chow, J., and Stanton, R.J., 1987. Late Neogene paleoceanography of the eastern Caribbean, the Gulf of Mexico, and the eastern Equatorial Pacific. Mar. Micropaleontol., 12:255-304.

Keller, G., and Barron, J.A., 1983. Paleoceanographic implications of Miocene deep-sea hiatuses. Geol. Soc. Am. Bull., 94:590-613.

, 1987. Paleodepth distribution of Neogene deep-sea hiatuses. Paleoceanography, 2:697-713.

Keller, G., Herbert, T., Dorsey, R., D’Hondt, S., Johnsson, M., and Chi, W.R., 1987. Global distribution of late Paleogene hiatuses. Geology, 15:199-203.

Manivit, H., 1989. Calcareous nannofossil biostratigraphy of Leg 108 sediments. In Ruddiman, W., Sarnthein, M., et al., Proc. ODP, Sci. Results, 108: College Station, TX (Ocean Drilling Program), 35-69.

Martini, E., 1971. Standard Tertiary and Quaternary calcareous nannoplankton zonation. In Farinacci, A. (Ed.), Proc. 2nd Int. Conf. Planktonic Microfossils Roma: Rome (Ed. Tecnosci.), 2:739-785. 
Mascle, J., Lohmann, G.P., Clift, P.D., et al., 1996. Proc. ODP, Init. Repts., 159: College Station, TX (Ocean Drilling Program).

Moore, T.C., Jr., van Andel, T.H., Sancetta, C., and Pisias, N., 1978. Cenozoic hiatuses in the pelagic sediments. Micropaleontology, 24:113-138.

Okada, H., 1983. Modern nannofossil assemblages in sediments of coastal and marginal seas along the western Pacific Ocean. In Meulenkamp, J.E. (Ed.), Reconstruction of Marine Paleoenvironments. Utrecht Micropaleontol. Bull., 30:171-1187.

Okada, H., and Bukry, D., 1980. Supplementary modification and introduction of code numbers to the low-latitude coccolith biostratigraphic zonation (Bukry, 1973; 1975). Mar. Micropaleontol., 5:321-325.

Olafsson, G., 1989. Quantitative calcareous nannofossil biostratigraphy of upper Oligocene to middle Miocene sediment from ODP Hole 667A and middle Miocene sediment from DSDP Site 574. In Ruddiman, W., Sarnthein, M., et al., Proc. ODP, Sci. Results, 108: College Station, TX (Ocean Drilling Program), 9-22.

, 1991. Quantitative calcareous nannofossil biostratigraphy and biochronology of early through late Miocene sediments from DSDP Hole 608. Medd. Stockholm Univ. Inst. Geol. Geochem., 203:1-28.

Peleo-Alampay, A.M., and Wei, W., 1995. Magnetobiochronology of several Miocene nannofossil datums at DSDP Site 563 revisited. Rev. Esp. Micropaleontol., 26:97-110.

Perch-Nielsen, K., 1985. Cenozoic calcareous nannofossils. In Bolli, H.M., Saunders, J.B., and Perch-Nielsen, K. (Eds.), Plankton Stratigraphy: Cambridge (Cambridge Univ. Press), 427-554.

Raffi, I., and Flores, J.-A., 1995. Pleistocene through Miocene calcareous nannofossils from eastern equatorial Pacific Ocean (Leg 138). In Pisias, N.G., Mayer, L.A., Janecek, T.R., Palmer-Julson, A., and van Andel, T.H. (Eds.), Proc. ODP, Sci. Results, 138: College Station, TX (Ocean Drilling Program), 233-286.

Raffi, I., and Rio, D., 1979. Calcareous nannofossil biostratigraphy of DSDP Site 132-Leg 13 (Tyrrhenian Sea-Western Mediterranean). Riv. Ital. Paleontol. Stratigr., 85:127-172.

Raffi, I., Rio, D., d'Atri, A., Fornaciari, E., and Rocchetti, S., 1995. Quantitative distribution patterns and biomagnetostratigraphy of middle and late Miocene calcareous nannofossils from equatorial Indian and Pacific oceans (Legs 115, 130, and 138). In Pisias, N.G., Mayer, L.A., Janecek, T.R., Palmer-Julson, A., and van Andel, T.H. (Eds.), Proc. ODP, Sci. Results, 138: College Station, TX (Ocean Drilling Program), 479-502.

Rio, D., Fornaciari, E., and Raffi, I., 1990a. Late Oligocene through early Pleistocene calcareous nannofossils from western equatorial Indian Ocean (Leg 115). In Duncan, R.A., Backman, J., Peterson, L.C., et al., Proc. ODP, Sci. Results, 115: College Station, TX (Ocean Drilling Program), 175-235.

Rio, D., Raffi, I., and Villa, G., 1990b. Pliocene-Pleistocene calcareous nannofossil distribution patterns in the Western Mediterranean. In Kastens, K.A., Mascle, J., et al., Proc. ODP, Sci. Results, 107: College Station, TX (Ocean Drilling Program), 513-533.

Rona, P.A., 1973. Worldwide unconformities in marine sediments related to eustatic changes of sea level. Nature Phys. Sci., 244:25.

Roth, P.H., and Thierstein, H., 1972. Calcareous nannoplankton: Leg 14 of the Deep Sea Drilling Project. In Hayes, D.E., Pimm, A.C., et al., Init. Repts. DSDP, 14: Washington (U.S. Govt. Printing Office), 421-485.

Samtleben, C., 1980. Die Evolution der Coccolithophoriden-Gattung Gephyrocapsa nach Befunden im Atlantik. Palaontol. Z., 54:91-127.

Shafik, S., 1975. Nannofossil biostratigraphy of the southwest Pacific, Deep Sea Drilling Project, Leg 30. In Andrews, J.E., Packham, G., et al., Init. Repts. DSDP, 30: Washington (U.S. Govt. Printing Office), 549-598

1996. Calcareous microplankton biostratigraphy of the Eocene Browns Creek Clay in the Aire District, Otway Basin of southern Australia: an update. AGSO J. Austr. Geol. Geophys., 16:333-344.

Theodoridis, S., 1984. Calcareous nannofossil biozonation of the Miocene and revision of the helicoliths and discoasters. Utrecht Micropaleontol. Bull., 32:1-271.

Young, J.R., 1990. Size variation of Neogene Reticulofenestra coccoliths from Indian Ocean DSDP cores. J. Micropaleontol., 9:71-85.

\footnotetext{
Date of initial receipt: 23 September 1996

Date of acceptance: 5 August 1997

Ms 159SR-022
}

\section{APPENDIX}

\section{Calcareous Nannofossils Considered in This Chapter}

(in alphabetical order of generic epithets)

Neogene and Pleistocene species

Amaurolithus amplificus (Bukry and Percival, 1971) Gartner and Bukry, 1975

Amaurolithus bizzarus (Bukry, 1973) Gartner and Bukry, 1975

Amaurolithus delicatus Gartner and Bukry, 1975

Amaurolithus primus (Bukry and Percival, 1971) Gartner and Bukry, 1975

Amaurolithus tricorniculatus (Gartner, 1967) Gartner and Bukry, 1975

Calcidiscus leptoporus (Murray and Blackman, 1898) Loeblich and Tappan, 1978

Calcidiscus macintyrei (Bukry and Bramlette, 1969) Loeblich and Tappan, 1978

Catinaster calyculus Martini and Bramlette, 1969

Catinaster coalitus Martini and Bramlette, 1969

Catinaster mexicanus Bukry, 1971

Ceratolithus acutus Gartner and Bukry, 1974

Ceratolithus armatus Müller, 1974

Ceratolithus armatus/rugosus (a transitional form between the two species)

Ceratolithus cristatus Kamptner, 1950

Ceratolithus rugosus Bukry and Bramlette, 1968

Ceratolithus separatus Bukry, 1979

Ceratolithus simplex Bukry, 1979

Clausioccus fenestratus (Deflandre and Fert, 1954) Prins, 1979

Coccolithus eopelagicus (Bramlette and Riedel, 1954) Bramlette and Sullivan, 1961

Coccolithus miopelagicus Bukry, 1971

Coccolithus pelagicus (Wallich, 1877) Schiller, 1930

Coronocyclus nitescens (Kamptner, 1963) Bramlette and Wilcoxon, 1967

Cyclicargolithus abisectus (Müller, 1970) Wise, 1973

Cyclicargolithus floridanus (Roth and Hay in Hay et al., 1967) Bukry, 1971

Discoaster adamanteus Bramlette and Wilcoxon, 1967

Discoaster asymmetricus Gartner, 1969

Discoaster berggrenii Bukry, 1971

Discoaster blackstockae Bukry, 1973

Discoaster bollii Martini and Bramlette, 1969

Discoaster braarudii Bukry, 1971

Discoaster brouweri Tan, 1927 emend. Bramlette and Riedel, 1954

Discoaster calcaris Gartner, 1967

Discoaster challengeri Bramlette and Riedel, 1954

Discoaster decorus (Bukry, 1971) Bukry, 1973

Discoaster deflandrei Bramlette and Riedel, 1954

Discoaster druggii Bramlette and Wilcoxon, 1967

Discoaster exilis Martini and Bramlette, 1963

Discoaster hamatus Martini and Bramlette, 1963

Discoaster icarus Stradner, 1973

Discoaster intercalaris Hay in Hay et al., 1967

Discoaster kugleri Martini and Bramlette, 1963

Discoaster loeblichii Bukry, 1971

Discoaster lidzi Hay in Hay et al., 1967

Discoaster moorei Bukry and Percival, 1971

Discoaster neohamatus Bukry and Bramlette, 1969

Discoaster neorectus Bukry, 1971

Discoaster nephados Hay in Hay et al., 1967

Discoaster obtusus Gartner, 1967

Discoaster pansus (Bukry and Percival, 1971) Bukry, 1973

Discoaster pentaradiatus Tan, 1927 emend. Bramlette and Riedel, 1954

Discoaster petaliformis Moshkvitz and Ehrlich, 1980

Discoaster prepentaradiatus Bukry and Percival, 1971

Discoaster pseudovariabilis Martini and Worsley, 1971

Discoaster quadramus Bukry, 1973

Discoaster quinqueramus Gartner, 1969

Discoaster sanmiguelensis Bukry, 1981

Discoaster saundersii Hay in Hay et al., 1967

Discoaster signus Bukry, 1971

Discoaster subsurculus Gartner, 1967

Discoaster surculus Martini and Bramlette, 1963

Discoaster tamalis Kamptner, 1967

Discoaster toralis Ellis, Lohmann, and Wray, 1972

Discoaster triradiatus Tan, 1927

Discoaster tristellifer Bukry, 1976

Discoaster variabilis Martini and Bramlette, 1963 
Emiliania huxleyi (Lohmann, 1902) Hay and Mohler in Hay et al., 1967

Florisphaera profunda Okada and Honjo, 1973

Geminilithella rotula (Kamptner, 1956) Backman, 1980

Gephyrocapsa aperta Kamptner, 1963

Gephyrocapsa caribbeanica Boudreau and Hay, 1969

Gephyrocapsa oceanica Kamptner, 1943

Gephyrocapsa margerellii Breheret, 1978

Gephyrocapsa omega Bukry, 1973

Hayaster perplexus (Bramlette and Riedel, 1954) Bukry, 1973

Helicosphaera acuta Theodordis, 1984

Helicosphaera ampliaperta Bramlette and Wilcoxon, 1967

Helicosphaera burkei Black, 1971

Helicosphaera carteri (Wallich, 1977) Kamptner, 1953

Helicosphaera elongata Theodordis, 1984

Helicosphaera euphratis Haq, 1966

Helicosphaera granulata (Bukry and Percival, 1971) Jafar and Martini, 1975

Helicosphaera hyalina Gaarder, 1970

Helicosphaera intermedia Martini, 1965

Helicosphaera inversa (Gartner, 1977) Gartner, 1980

Helicosphaera kamptneri Hay and Mohler in Hay et al., 1967

Helicosphaera mediterranea Müller, 1981

Helicosphaera obliqua Bramlette and Wilcoxon, 1967

Helicosphaera orientalis Black, 1971

Helicosphaera recta $\mathrm{Haq}, 1966$

Helicosphaera rhomba (Bukry, 1971) Haq and Berggren, 1978

Helicosphaera scissura Miller, 1981

Helicosphaera sellii (Bukry and Bramlette, 1969) Jafar and Martini, 1975

Helicosphaera stalis Theodordis, 1984

Helicosphaera truempyi Biolzi and Perch-Nielsen, 1982

Minylitha convallis Bukry, 1973

Orthorhabdus serratus Bramlette and Wilcoxon, 1967

Pontosphaera indooceanica Cepek, 1973

Pontosphaera japonica (Takayama, 1967) Nishida, 1971

Pontosphaera multipora (Kamptner, 1948) Roth, 1970

Pontosphaera plana (Bramlette and Sullivan, 1961) Haq, 1971

Pseudoemiliania lacunosa (Kamptner, 1963) Gartner, 1969

Reticulofenestra ampliumbilicus Theodordis, 1984
Reticulofenestra astoni Sato and Takayama, 1992

Reticulofenestra haqii Backman, 1978

Reticulofenestra lockeri Müller, 1970

Reticulofenestra minuta Roth, 1970

Reticulofenestra minutula (Gartner, 1967) Haq and Berggren, 1978

Reticulofenestra pseudoumbilicus (Gartner, 1967) Gartner, 1969

Reticulofenestra rotalia Theodordis, 1984

Rhabdosphaera clavigera Murray and Blackman, 1898

Scapholithus fossilis Deflandre in Deflandre and Fert, 1954

Solidopons petrae Theodordis, 1984

Sphenolithus abies Deflandre in Deflandre and Fert, 1954

Sphenolithus belemnos Bramlette and Wilcoxon, 1967

Sphenolithus capricornutus Bukry and Percival, 1971

Sphenolithus ciperoensis Bramlette and Wilcoxon, 1967

Sphenolithus compactus Backman, 1980

Sphenolithus conicus Bukry, 1971

Sphenolithus dissimilis Bukry and Percival, 1971

Sphenolithus elongatus Perch-Nielsen, 1980

Sphenolithus heteromorphus Deflandre, 1953

Sphenolithus moriformis (Brönnimann and Stradner, 1960) Bramlette and Wilcoxon, 1967

Sphenolithus neoabies Bukry and Bramlette, 1969

Syracosphaera pulchra Lohmann, 1902

Tetralithoides symeonidesii Theodordis, 1984

Triquetrorhabdulus auritus Stradner and Allram, 1982

Triquetrorhabdulus milowii Bukry, 1971

Triquetrorhabdulus carinatus Martini, 1965

Triquetrorhabdulus farnsworthii Gartner, 1967

Triquetrorhabdulus rugosus Bramlette and Wilcoxon, 1967

Umbilicosphaera irregularis Paasche, 1955

Umbilicosphaera sibogae (Weber-van Bosse, 1901) Gaarder, 1970

Older species

Chiasmolithus solitus (Bramlette and Sullivan, 1961) Locker, 1968

Cruciplacolithus tenuis (Stradner, 1961) Hay and Mohler in Hay et al., 1967

Gartnerago obliquum (Stradner, 1963) Noel, 1970

Isthmolithus recurvus Deflandre, 1954 